\title{
Enhancement of skin permeability with thermal ablation techniques: concept to commercial products
}

\author{
Rabinarayan Parhi ${ }^{1}$ (D) Aishwarya Mandru ${ }^{2}$
}

Published online: 21 July 2020

(C) Controlled Release Society 2020

\begin{abstract}
Traditionally, the skin is considered as a protective barrier which acts as a highly impermeable region of the human body. But in recent times, it is recognized as a specialized organ that aids in the delivery of a wide range of drug molecules into the skin (intradermal drug delivery) and across the skin into systemic circulation (transdermal drug delivery, TDD). The bioavailability of a drug administered transdermally can be improved by several penetration enhancement techniques, which are broadly classified into chemical and physical techniques. Application of mentioned techniques together with efforts of various scientific and innovative companies had made TDD a multibillion dollar market and an average of 2.6 new transdermal drugs are being approved each year. Out of various techniques, the thermal ablation techniques involving chemicals, heating elements, lasers, and radiofrequency (RF) are proved to be more effective in terms of delivering the drug across the skin by disrupting the stratum corneum (SC). The reason behind it is that the thermal ablation technique resulted in improved bioavailability, quick treatment and fast recovery of the SC, and more importantly it does not cause any damage to underlying dermis layer. This review article mainly discussed about various thermal ablation techniques with commercial products and patents in each classes, and their safety aspects. This review also briefly presented anatomy of the skin, penetration pathways across the skin, and different generations of TDD.
\end{abstract}

Keywords Transdermal drug delivery $\cdot$ Stratum corneum · Physical approaches · Penetration enhancement · Thermal ablation · Radiofrequency

\section{Introduction}

Undoubtedly, the skin is the largest organ in our body and it roughly accounts for $15 \%$ of the total body mass. It has varying surface area of 1.5 to $2.0 \mathrm{~m}^{2}$ based on the anatomical site and gender $[1,2]$. The skin is regarded as a critical protective layer and plays an important homeostatic role [3]. It is a multilayered organ, basically having three layers: epidermis, dermis, and subcutaneous layers. All these layers are different

Rabinarayan Parhi rabi59bls623@gmail.com

1 Department of Pharmaceutical Sciences, Susruta School of Medical and Paramedical Sciences, Assam University (A Central University), Silchar, Assam 788011, India

2 GITAM Institute of Pharmacy, Gandhi Institute of Technology and Management (GITAM), Deemed to be University, Gandhi Nagar Campus, Rushikonda, Visakhapatnam, Andhra Pradesh 530045, India from each other with regard to morphology and function. The skin continues to be the centre of huge research interest due to its huge accessible large surface area $[4,5]$. However, $\mathrm{SC}$, the outer layer of skin, is a formidable barrier which poses a biggest challenge for many drugs to be delivered through the skin. Therefore, to be therapeutically successful, this barrier nature of the skin must be altered in such a way that the drug can be administered at rate sufficient enough to achieve desired plasma concentration [6].

Delivery of drugs into systemic circulation via skin is termed as TDD. TDD has many potential advantages compared with (a) oral drug delivery such as avoidance of firstpass metabolism and harsh environment of the stomach, minimization of inter- and intra-patient variation, higher patient acceptance and comfort level, promotion of controlled and reproducible drug delivery, delivery of drugs with short biological half-life and narrow therapeutic index, possibility of self-administration, and ease of termination in case of side effects [7-10], and compared with (b) parenteral route such as needleless administration of drug (i.e. no pain to the 
patient), and reduction of possible infections and compliance issues [11]. Despite all the above benefits, TDD was explored much after the approval of first transdermal patch, called Transderm Scope ${ }^{\circledR}$ (Alza Corporation, USA) by the Food and Drug Administration (FDA) in 1979. Prior to this, TDD was restricted to simple drug delivery vehicles such as ointments and gels with very few active ingredients (e.g. nitroglycerine and estradiol). Later in 1981, nitroglycerine patches for prevention of angina were approved by the FDA for marketing. However, the transdermal route of drug delivery gained huge acceptability among patients only after nicotine patches for smoking cessation were introduced in 1991.

However, TDD is not flawless for drug transport as it has many challenges, including the barrier property of SC, and variability in penetration among individuals and among different skin locations of an individual [12]. In addition, lag in onset of action and lack of pharmacokinetic control may also diminish the reliability of TDD [13]. As a result, only the drug molecules having low molecular weight (MW < $500 \mathrm{Da})$, a balanced lipophilicity ( $\log P$ (octanol/water), ideally 2 to 3 ) and hydrophilicity (aqueous solubility $>100 \mu \mathrm{g} / \mathrm{ml}$ ), and small-dose drugs with $<10 \mathrm{mg} /$ day requirement and melting point $<200^{\circ} \mathrm{C}$ are suitable candidates for transdermal delivery [14]. Therefore, only very few lipophilic and small drug molecules are able to cross the skin passively. On the other hand, hydrophilic drugs and macromolecules such as protein, peptides, and vaccines can not permeate through the skin in desired rate.

To circumvent above limitation, years of research and development culminated into two approaches, namely chemical/ passive and physical/active approaches. Chemical methods include modification of the SC permeability by influencing drug and vehicle interaction, and formulation optimization. In this method, the rate of drug diffusion mainly depends on MW as well as concentration gradient leading to difficulty even impossible to deliver large molecules across skin in time-controlled manner. Lag time in drug release may be the major limitation of chemical method which incurred with certain negative influence on rapid onset of action [15]. In chemical method, various classes of penetration enhancers are being incorporated into transdermal formulations to enhance the skin permeability [16]. It was reported that penetration enhancers, particularly organic solvents and surfactants, induce different skin ailments such as contact urticaria, erythema, and burning sensation [17]. In addition, there is no report in the literature on the long-term effect of penetration enhancers on the skin and particularly on the SC [18]. Active methods use the application of external energy as driving force or by physically disrupting the SC for enhancing drug transport through skin. This enables delivery of many drugs including lipophilic, hydrophilic, and macromolecules. This method also offers higher control over drug delivery profiles resulting in shorter lag period compared with chemical methods. In addition, the devices and their application parameters can be optimized to suite skin properties of individual patient [19]. Therefore, under physical approach, many techniques including iontophoresis, sonophoresis, electroporation, pressure waves, magnetophoresis, high-velocity jets, microneedles, tape stripping, and the SC ablation were successfully employed. All these techniques are having their advantages and disadvantages. For instance, iontophoresis, phonophoresis, and novel microneedle techniques induce pain at the administration site. One of the advantages of microneedles is being non-invasive. However, an additional step of sterilization of microneedles increases the cost of dosage regimen [17].

Thermal ablation is a promising technique for enhancing the permeability of the SC as it provides non-invasive drug delivery through microchannels created in the skin. These microchannels are still small enough to avoid undesirable effects such as pain, bleeding, irritation, and infection. Additionally, this technique has better control over physical and physiological impact on the skin. Furthermore, it offers effective delivery of high MW compounds such as proteins and peptides [20]. The technique involves treating the skin to the temperature well above $100{ }^{\circ} \mathrm{C}$ for sub-second which proved to be beneficial in enhancing the skin permeability. The intention of this technique is to create a high degree of temperature gradient across the SC. This leads to heating and vaporization of the SC either partially or fully, without damaging the skin underneath. Thermal ablation can be performed by (i) chemical heating, (ii) heating element-based thermoporation, (iii) RF, and (iv) laser [20, 21]. Therefore, this review mainly focused on different thermal ablation techniques with their advantages, disadvantages, marketed products, patents, and safety issues. This review also discussed briefly about the anatomy of the skin, different skin permeation pathways, and different generations of TDD.

\section{Structure of the skin}

The skin is the external covering or integument of the human body which receives about $1 / 3$ circulating blood. Taking several factors into consideration like anatomy, age, and sex, functions of the skin are classified as protective, homeostatic, or sensorial. The skin is composed of three main layers: epidermis, dermis, and hypodermis as shown in Fig. 1 [22, 23].

\section{Epidermis}

Depending upon the number of layers and size of the cells, the epidermis varies in thickness from one individual to another and also from region to region of an individual. The epidermis is multi-layered and is divided into two main regions: (i) nonviable epidermis and (ii) viable epidermis. 
Fig. 1 Structure of human skin

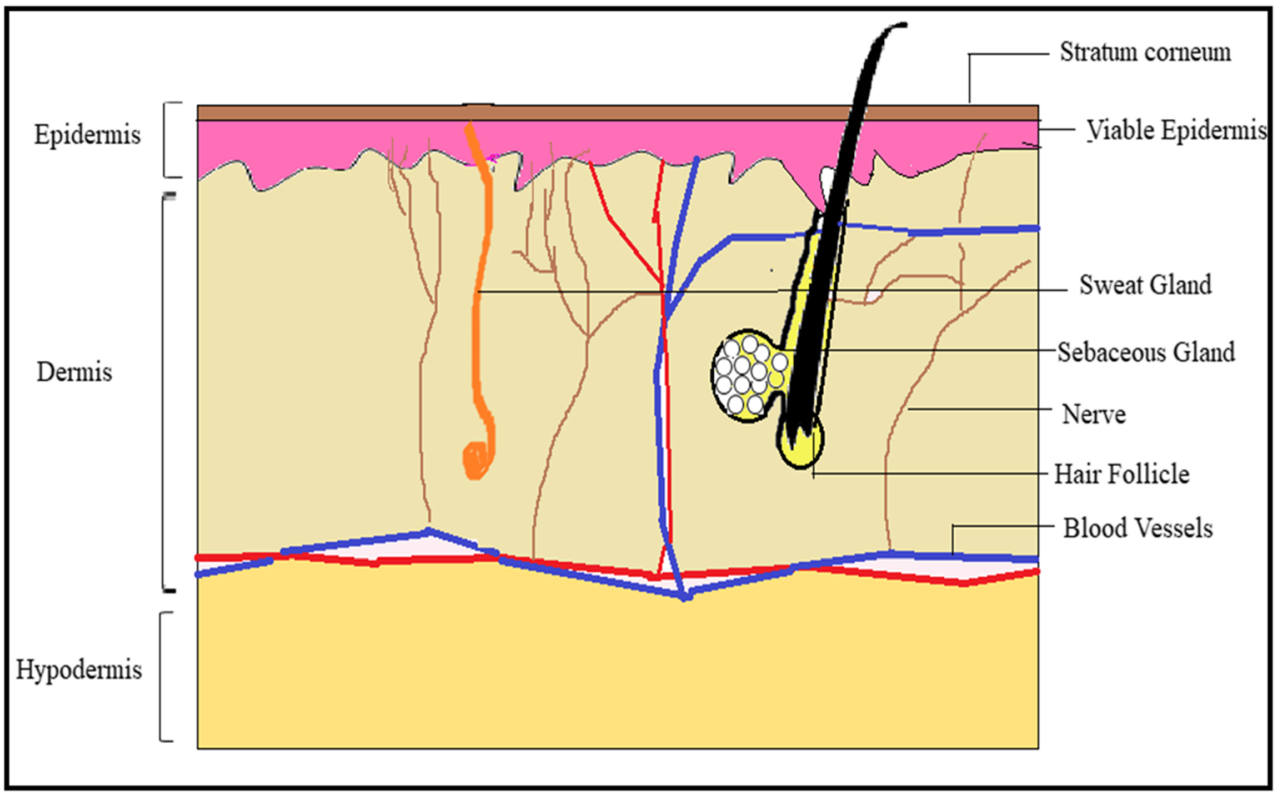

\section{Non-viable epidermis (SC)}

The SC is also called as horny layer which is the outermost layer of human skin and is about $10 \mathrm{~mm}$ thick in the dry state and when hydrated it swells many-fold in its thickness [10, 24]. It is composed of keratinized cells called corneocytes, which are arranged in multiple lipid bilayers. It serves as the main absorption barrier for the permeation of drugs with its unique 'brick and mortar' structure, where corneocytes are depicted as bricks and bilipid layers are assumed as mortar, due to its resembles with wall having bricks and cement mixture in between $[25,26]$.

\section{Viable epidermis}

It is located beneath the SC and is divided into four layers, viz., stratum lucidum, stratum granulosum, stratum spinosum, and stratum germinativum [10]. Stratum lucidum is also called a clear layer, usually made up of flat, clear, dead keratinocytes. Stratum granulosum constitutes 2 to 4 cell layers of keratinocytes and its thickness is $3 \mu \mathrm{m}$. Stratum spinosum or prickle cell layer lies just above the basal cell layer and composed of 8-10 layers of polygonal keratinocytes which are conjugated by desmosomes having thickness of about 50 $150 \mu \mathrm{m}$. Stratum basale is an innermost layer of the epidermis and composed of a single layer of basal cells. It helps to retain the water (approx. 8\%) but losses its ability with age [3].

\section{Dermis}

The dermis region is a 3-4-mm-thick layer and constitutes a matrix of connective tissues, blood vessels, sweat glands, hair follicles, lymph vessels, and nerves. The connective tissues such as collagen and elastic fibres provide strength and flexibility to the skin, respectively [3].

\section{Hypodermis/subcutaneous layer}

The hypodermis is richly supplied with larger blood vessels and lymph vessels. It acts as a support system for the dermis and epidermis and also as a fat storage zone. This layer provides mechanical strength and also regulates body temperature. It constitutes blood vessels, and nerves to skin and sensory pressure organs [25].

\section{Penetration pathways for drug absorption}

Depending on physicochemical properties of the drug and the site of drug/formulation application, the drug can have two potential routes: transepidermal route and transappendageal route or trans-follicular route [Fig. 2] [8].

\section{Transepidermal route}

The route, excluding trans-follicular region, through which applied drug molecules permeate the skin is called as transepidermal route. In this route, there are two pathways available for the drug permeation: transcellular/intracellular and intercellular/paracellular routes.

\section{Transcellular route (intracellular route)}

Transcellular pathway (across the cells) ensures the movement of drugs across the alternate layers of hydrophilic corneocytes 
Fig. 2 Penetration pathways in skin

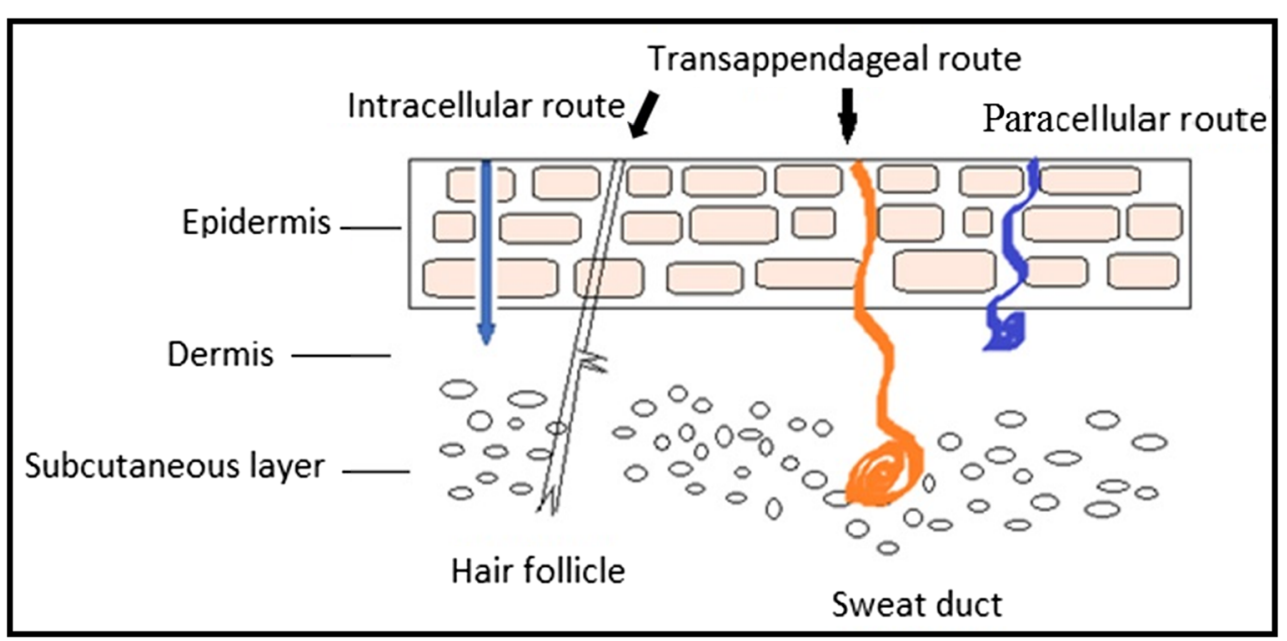

and lipophilic lipid bilayers. Hence, this pathway requires both partitioning and diffusion steps in order to enter into systemic circulation. Therefore, transcellular penetration of drug molecules is unlikely to happen [27].

\section{Intercellular route (paracellular route)}

In intercellular pathway, the drug molecules permeate through continuous lipid matrix which is present between the corneocytes. This route is the most suitable and prevalent route for drug permeation for lipophilic substances as they have to diffuse through only lipid matrix. There are two extreme polarities present: hydrophilic environment formed by the polar head groups of the lipid bilayer and lipophilic characteristics due to the presence of long non-polar lipid chains. The later has the wider section within the bilipid layer. Thus, the permeability of lipophilic solutes changed with the degree of lipophilicity, whereas permeation of highly polar solute across the SC was proved to be almost constant [28]. One disadvantage of this pathway is that drug molecules have to cross longer distance $[29,30]$.

\section{Trans-follicular route (shunt pathway)}

The routes through the sweat gland, sebaceous gland, and hair follicle-associated sebaceous glands (pilosebaceous gland) are envisaged as transappendageal route. It is also called as shunt channels as drug molecules present in the topically applied formulations can bypass the SC barrier and even the viable epidermis to reach the underlying dermal layer. It is reported in the literature that transappendageal route is responsible for the diffusion of high MW solutes, nano-sized particles such as polymeric nanoparticles, and liposomes, cyclodextrin inclusion complexes, and slowly diffusing compounds $[29,31,32]$.

\section{Generations of transdermal delivery system}

Even though there are pathways for drugs to cross the skin barrier in order to reach systemic circulation, they are unable to do so for most of the drugs due to their limitations. In order to circumvent these limitations, TDD has been evolved through several generations, focusing mainly on mechanisms of different methods to enhance drug permeation across skin and the extent of safety it can provide towards skin. These generations of TDD had used drug formulation strategy and passive diffusion in first-generation, non-invasive TDDS (transdermal drug delivery system) with external stimulation in second generation and minimal invasion in third generation [13] (Fig. 3).

\section{First generation}

First-generation TDDS exclusively focussed on delivering the drug across the skin on the basis of passive diffusion capability of the drug. Transdermal systems such as membrane-permeated/reservoir/matrix adhesive systems are included in first-generation systems [29, 33]. Soon after the approval of first transdermal patch by the US-FDA, there are approximately 19 transdermal patches that came to the market due to their better patient compliance [34]. However, the popularity of transdermal patches diminished very quickly when it was realized that only the drug molecules having specific physicochemical properties such as low MW, low daily dose, and high partition coefficient can only be considered for transdermal patch development. Therefore, the first-generation TDD is basically limited by its permeation across SC. However, this scenario can be reversed by tailoring more drug candidates in terms of physicochemical properties, to render them suitable for TDD [33]. 
Fig. 3 Different TDDS generations with their penetration enhancing techniques

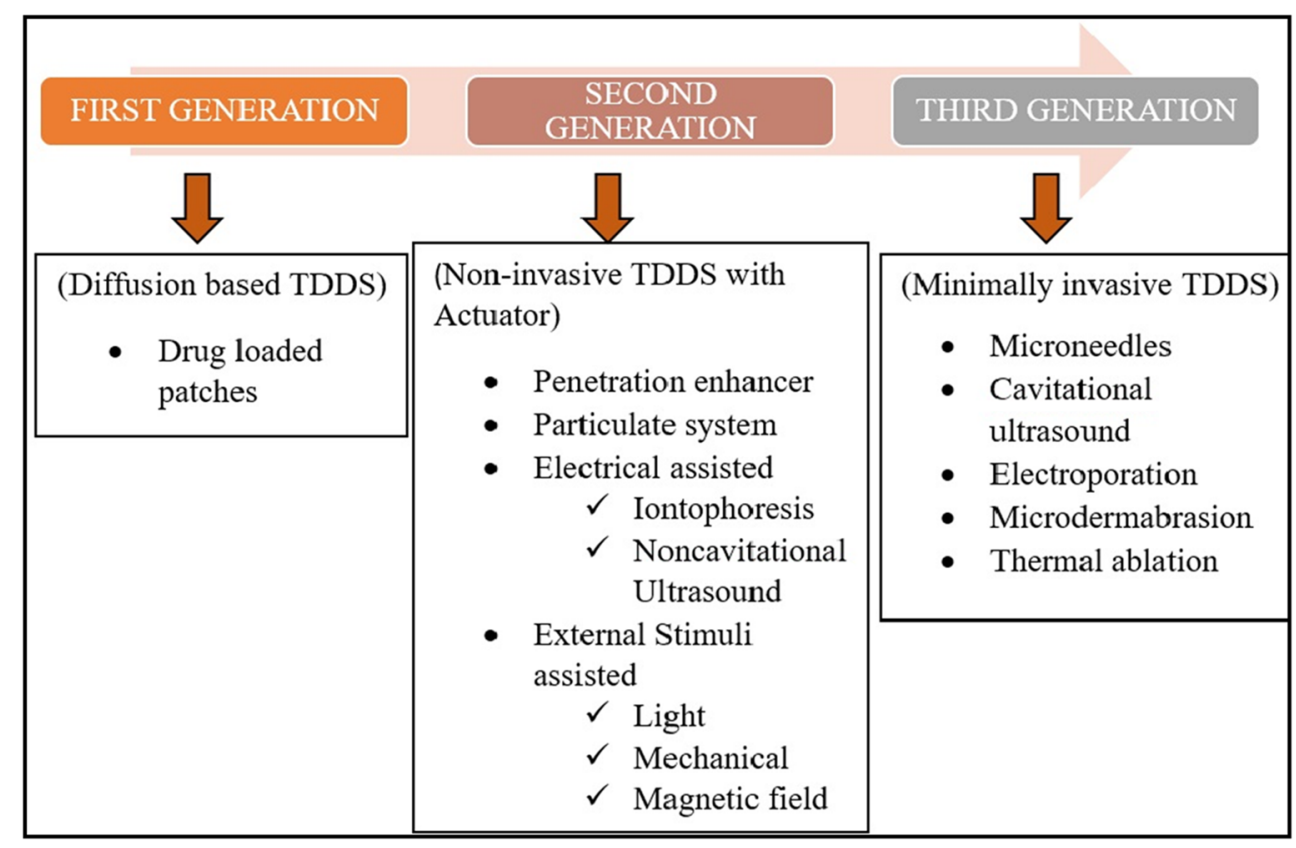

\section{Second generation}

The second-generation transdermal systems deal with the different non-invasive enhancement techniques to increase drug permeation across the skin, including the use of chemical penetration enhancers [33,35], particulate systems (e.g. emulsion and nanocarriers) [36-39], external stimuli assisted (e.g. light, mechanical force and magnetic field) [40-42], and electrically assisted techniques (e.g. iontophoresis, non-cavitational ultrasound) [43, 44]. Emulsion has the advantage of incorporating both hydrophilic and hydrophobic drugs within it. Emulsion of nano- or micron size and other nanocarriers such as liposomes and polymeric nanoparticles can permeate the tight junctions of skin barrier [45-47]. Iontophoresis involves the application of a weak electrical current below $500 \mu \mathrm{A} / \mathrm{cm}^{2}$, which has the ability to propel, preferably, the ionized drug across the skin. It has the advantages of stretching the MW limit of the solute up to $1000 \mathrm{Da}$ and daily dose up to $50 \mathrm{mg}$ [17].

\section{Third generation}

Penetration of large hydrophilic molecules and macromolecules such as DNA, therapeutic proteins, and vaccines across the skin is a challenge for techniques in second generation. Therefore, an alternative approach of minimally invasive methods is adopted to address the mentioned issues and all such methods are clubbed in third-generation TDD techniques [48]. In third generation, microscopic destruction of the epidermis was performed to facilitate the delivery of drug molecules, including microneedles, cavitational ultrasound, electrophoresis, microdermabration, and thermal ablation $[29,33]$. Out of them, microneedle and thermal ablation techniques are being widely used. Microneedles, composed of micron-sized needles, are micro-invasive TDD technique which can be used to create transient aqueous conduits for easy delivery of diverse drug candidates [17, 49-52]. Thermal ablation techniques uses high-energy sources to remove the SC, either partially or completely, to improve drug permeation across the skin (thoroughly discussed later).

\section{Techniques to enhance skin permeation}

The barrier properties of the SC are manipulated by utilizing different technologies. These technologies are divided into passive/chemical or active/physical approaches $[16,53]$. The principles and mechanisms of action of various methods/ techniques under mentioned approaches are briefly discussed as follows.

\section{Passive/chemical methods}

Passive methods involve the modification of the SC by utilizing drug and vehicle interactions, followed by formulation optimization. Passive methods use penetration enhancers, supersaturated systems, prodrugs, liposomes, and other vesicles. All these methods have their own advantages and disadvantages. Among all, an immensely used passive approach is chemical penetration enhancers which assisted the drug to cross the SC without damaging the skin. This is because the incorporation of chemical penetration enhancers into 
transdermal patches and other formulations is easy compared with physical methods involving external stimuli. Chemical penetration enhancers would act by one or more of the following mechanisms [54]: (i) disrupting highly ordered bilipid structure of the SC (e.g. terpenes and azones) and enhancing drug permeation across intercellular route, (ii) interacting with protein structure of corneocytes (e.g. pyrrolidones, dimethylformamide, dimethyl sulphoxide), thereby opening up intracellular pathway, and (iii) improving of partitioning of solute across the SC (e.g. propylene glycol, polyethylene glycol) [3]. Skin permeability is exponentially enhanced by using chemical permeation enhancers which work by partitioning the drug in SC. The main obstacle of this method is a delay in drug release that will affect the rapid onset of action (increase in lag time). The currently marketed patches have shown some issues like irritancy and inadequate adhesion of patch. Furthermore, the size of the patch is restricted to $\leq 40 \mathrm{~cm}^{2}$, so the amount of drug load is also reduced [54]. In addition, the impotency of delivering large solute molecules through the skin by passive methods directed in developing different physical strategies.

\section{Active/physical methods}

In comparison with chemical methods, active or physical techniques are worthwhile in providing superior flexibility in composing a formulation and easy administration $[16,55]$. To boost the permeation of the drug molecules into the skin, this method utilizes the external energy as a driving force to decline the barrier properties of SC. Recent advances have assisted in the creation of powerful devices that can bring about an essential clinical response. Active methods have achieved a priority which eventually led to the delivery of large MW (>500 Da) hydrophilic molecules, such as proteins and peptides. Active/assisted enhancement techniques are under development to deliver biologics and large molecules. There are many physical methods across the generations. However, this review has mainly focus on thermal ablation technique.

\section{Thermal ablation}

Thermal ablation, also known as thermophoresis, involves the depletion or removal of the SC by the application of heat to enhance the drug permeation across the skin [15, 21]. Thermal ablation is a physical technique in which the SC is selectively vaporized followed by its removal from the skin surface, without damaging deeper tissue [21]. Therefore, the thermal exposure should be for short duration so that temperature gradient across the SC can be higher to maintain significant skin surface temperature compared with the underneath viable epidermis [56]. It can be achieved in two ways: (i) moderate temperature $\left(\leq 100^{\circ} \mathrm{C}\right)$ and long time, and (ii) very high temperature $\left(\geq 100^{\circ} \mathrm{C}\right)$ and short period. It is worthy to mention that the duration of thermal exposure was ranged from $1 \mu$ s to $100 \mathrm{~ms}$. However, the second option is in great use because the SC temperature will be significantly increased due to high temperature; at the same time; no damage is being caused to deeper tissue due to short period of exposure. Following are the advantages of thermal ablation compared with other techniques [21]:

i. Thermal ablation is a very efficient physical technique compared with enhancement techniques in second and third generation.

ii. This technique can deliver small molecules as well as macromolecules and vaccines.

iii. Sterilization of microneedles is essential, but not the thermal ablation equipment.

iv. It does not require charges on the solute molecules to be delivered across the skin as required in iontophoresis.

v. Compared with chemical penetration enhancement, where alteration in formulation is performed in order to incorporate it, thermal ablation does not require any change in formulation.

vi. Thermal ablation can be performed by various ways such as chemicals, RF, and laser.

\section{Different methods to achieve thermal ablation}

Thermal ablation can be achieved by the following methods: (i) chemical heating, (ii) thermoporation, (iii) RF, and (iv) laser. Table 1 indicates various FDA-approved commercial products and products in pipeline of each method along with their advantages and disadvantages.

\section{Chemical heating based thermal ablation}

Heat generated by chemical means has been used to enhance drug permeation across the skin. For local increase in temperature, an initiator is essential along with a chemical agent. The intensity of heat generated depends on the initiator. Generally, there are two initiators such as oxygen and water employed in commercial transdermal patches [57, 60]. An additional air permeable pouch is packed with the patches wherever oxygen is used as initiator. Heat is generated once oxygen comes in contact with the reaction mixture. This resulted in maintaining skin temperature approximately $42{ }^{\circ} \mathrm{C}$ for $\geq 4 \mathrm{~h}$. However, the use of water as initiator can increase the temperature of the skin surface sharply up to $65^{\circ} \mathrm{C}$, which deemed to be very effective compared with oxygen. The chemical agent used 
Table 1 List of FDA-approved commercial products and pipeline products in different clinical phases of each thermal ablation method along with their advantages and disadvantages [57-59]

\begin{tabular}{|c|c|c|c|c|c|c|c|}
\hline $\begin{array}{l}\text { Thermal ablation } \\
\text { methods }\end{array}$ & $\begin{array}{l}\text { Commercial/pipeline } \\
\text { products }\end{array}$ & Company & Drug & $\begin{array}{l}\text { Phase } \\
\text { in } \\
\text { clinical } \\
\text { trials }\end{array}$ & Application & Advantages & Disadvantages \\
\hline \multirow{3}{*}{$\begin{array}{l}\text { A. Chemical } \\
\text { heating (iron } \\
\text { oxide } \\
\text { reaction/CHA- } \\
\text { DD) } \\
\text { (i) Commercial } \\
\text { products } \\
\text { (ii) Pipeline } \\
\text { products }\end{array}$} & $\begin{array}{l}\text { Synera }{ }, \text { Rapydan }{ }^{\circledR} \\
\text {-Iron oxide }\end{array}$ & $\begin{array}{l}\text { Nuvo } \\
\quad \text { Research } \\
\text { Inc., } \\
\text { Canada }\end{array}$ & Lidocaine/tetracaine & --- & Pain & \multirow[t]{3}{*}{$\begin{array}{l}\checkmark \text { Based on types } \\
\text { of initiator a } \\
\text { sharp as well as } \\
\text { slow and } \\
\text { controlled } \\
\text { temperature } \\
\text { increase can be } \\
\text { achieved }\end{array}$} & $\begin{array}{l}\checkmark \text { Requirement of } \\
\text { an additional } \\
\text { component } \\
\text { called initiator is } \\
\text { essential. }\end{array}$ \\
\hline & $\begin{array}{l}\text { a) Matrix transdermal } \\
\text { ketoprofen-CHAD- } \\
\mathrm{D}^{\mathrm{TM}}\end{array}$ & $\begin{array}{l}\text { Zars Pharma, } \\
\text { now } \\
\text { acquired by } \\
\text { Nuvo } \\
\text { Research } \\
\text { Inc., } \\
\text { Canada. }\end{array}$ & Ketoprofen & Phase-II & Osteoarthritis & & $\begin{array}{l}\checkmark \text { The permeation } \\
\text { enhancement } \\
\text { may be due to } \\
\text { thermodynamic } \\
\text { activity and } \\
\text { inherent } \\
\text { molecular }\end{array}$ \\
\hline & $\begin{array}{l}\text { b) Matrix transdermal } \\
\text { fentanyl-CHADD }\end{array}$ & $\begin{array}{l}\text { Zars Pharma, } \\
\text { now } \\
\text { acquired by } \\
\text { Nuvo } \\
\text { Research } \\
\text { Inc., } \\
\text { Canada. }\end{array}$ & Fentanyl & Phase-II & Pain & & $\begin{array}{l}\text { diffusion ability } \\
\text { of the } \\
\text { incorporated } \\
\text { drug in addition } \\
\text { to heating } \\
\text { mechanism. }\end{array}$ \\
\hline \multirow[t]{2}{*}{$\begin{array}{l}\text { B. } \\
\text { Thermoporatio- } \\
\mathrm{n} \\
\text { (i) Commercial } \\
\text { products }\end{array}$} & a) PassPort ${ }^{\mathrm{TM}}$ system & $\begin{array}{l}\text { Altea } \\
\text { Therapeuti- } \\
\text { cs Corp., } \\
\text { Atlanta, } \\
\text { GA }\end{array}$ & ----- & ----- & ---- & \multirow{5}{*}{$\begin{array}{l}\checkmark \text { Microporation } \\
\text { technique can } \\
\text { eliminate the risk } \\
\text { of blood-borne } \\
\text { pathogens trans- } \\
\text { mission due to } \\
\text { the use of } \\
\text { sterilizable and } \\
\text { disposable metal } \\
\text { filaments. }\end{array}$} & $\begin{array}{l}\checkmark \text { Generated excess } \\
\text { heat can damage } \\
\text { the deeper tissue } \\
\text { and even induce } \\
\text { thermohaemoly- } \\
\text { sis. }\end{array}$ \\
\hline & b) Tixel system & $\begin{array}{l}\text { Novoxel, } \\
\text { Landshut, } \\
\text { Germany }\end{array}$ & ---- & ---- & ---- & & $\begin{array}{l}\checkmark \text { Electric field } \\
\text { limitations may } \\
\text { be another }\end{array}$ \\
\hline \multirow[t]{3}{*}{$\begin{array}{l}\text { (ii) Pipeline } \\
\text { products }\end{array}$} & $\begin{array}{l}\text { a) Insulin- PassPort' } \\
\text { system. }\end{array}$ & $\begin{array}{l}\text { Nitto Denko, } \\
\text { Japan }\end{array}$ & Insulin & $\begin{array}{l}\text { Phase-I } \\
\text { and } \\
\text { Phas- } \\
\text { e-II }\end{array}$ & Diabetes & & $\begin{array}{l}\text { concern as the } \\
\text { filaments of the } \\
\text { device are } \\
\text { connected }\end{array}$ \\
\hline & $\begin{array}{l}\text { b) Apomorphine HCl- } \\
\text { PassPort }{ }^{\mathrm{TM}} \text { system }\end{array}$ & $\begin{array}{l}\text { Altea } \\
\text { Therapeuti- } \\
\text { cs Corp., } \\
\text { Atlanta, } \\
\text { GA. }\end{array}$ & Apomorphine $\mathrm{HCl}$ & Phase-I & $\begin{array}{l}\text { Management } \\
\text { of } \\
\text { Parkinso- } \\
\text { n's } \\
\text { Disease }\end{array}$ & & electrically. \\
\hline & $\begin{array}{l}\text { c) Fentanyl citrate- } \\
\text { PassPort }{ }^{\mathrm{TM}} \text { system. }\end{array}$ & $\begin{array}{l}\text { Altea } \\
\text { Therapeuti- } \\
\text { cs Corp., } \\
\text { Atlanta, } \\
\text { GA }\end{array}$ & Fentanyl citrate & Phase-I & $\begin{array}{l}\text { Acute and } \\
\text { chronic } \\
\text { pain }\end{array}$ & & \\
\hline $\begin{array}{l}\text { C. } \\
\text { Radiofrequenc- } \\
y \\
\text { (i) Commercial } \\
\text { products }\end{array}$ & ViaDor® system & $\begin{array}{l}\text { Syneron } \\
\text { Medical } \\
\text { Ltd., Israel }\end{array}$ & --- & --- & --- & $\begin{array}{l}\checkmark \text { The } \\
\text { microchannels } \\
\text { are formed } \\
\text { within } \\
\text { milliseconds. }\end{array}$ & $\begin{array}{l}\checkmark \text { This technique } \\
\text { may cause skin } \\
\text { damage of } \\
\text { serious nature, } \\
\text { when there is no }\end{array}$ \\
\hline $\begin{array}{l}\text { (ii) Pipeline } \\
\text { products }\end{array}$ & $\begin{array}{l}\text { a) hGh-ViaDor }{ }^{\circledR} \\
\text { system }\end{array}$ & $\begin{array}{l}\text { Teva } \\
\text { Neuroscie- } \\
\text { nce Inc., } \\
\text { US }\end{array}$ & $\begin{array}{l}\text { Human growth } \\
\text { hormone or } \\
\text { somatropin }\end{array}$ & Phase-I & $\begin{array}{l}\text { Growth } \\
\text { hormone } \\
\text { deficiency }\end{array}$ & $\begin{array}{l}\checkmark \text { Formed } \\
\text { microchannels } \\
\text { capable of } \\
\text { sustaining the } \\
\text { drug release in } \\
\text { order to maintain } \\
\text { desired blood } \\
\text { levels. }\end{array}$ & $\begin{array}{l}\text { appropriate } \\
\text { contact between } \\
\text { the applicator } \\
\text { and tissue or else } \\
\text { the applicator is } \\
\text { lifted. }\end{array}$ \\
\hline
\end{tabular}


Table 1 (continued)

\begin{tabular}{llllll}
\hline $\begin{array}{l}\text { Thermal ablation } \\
\text { methods }\end{array}$ & $\begin{array}{l}\text { Commercial/pipeline } \\
\text { products }\end{array}$ & Company & Drug & $\begin{array}{l}\text { Phase Application Advantages } \\
\text { in } \\
\text { clinical } \\
\text { trials }\end{array}$ & \\
& & Disadvantages & \\
& & & \\
& &
\end{tabular}

\begin{tabular}{|c|c|c|c|c|c|c|c|}
\hline & $\begin{array}{l}\text { b) Teriparatide- } \\
\text { ViaDor }{ }^{\circledR} \text { system }\end{array}$ & $\begin{array}{l}\text { Syneron } \\
\quad \text { Medical } \\
\text { Ltd., Israel } \\
\text { and Eli } \\
\text { Lilly }\end{array}$ & Teriparatide & Phase-II & Osteoporosis & $\begin{array}{l}\checkmark \text { It helps in } \\
\text { delivery of wide } \\
\text { range of drugs } \\
\text { with hydrophilic } \\
\text { nature and } \\
\text { macromolecules. }\end{array}$ & \\
\hline & $\begin{array}{l}\text { c) GLP1- ViaDor® } \\
\text { system }\end{array}$ & $\begin{array}{l}\text { Syneron } \\
\text { Medical } \\
\text { Ltd., Israel }\end{array}$ & $\begin{array}{l}\text { Glucagon like } \\
\text { peptide-I }\end{array}$ & Phase-I & Diabetes & $\begin{array}{l}\checkmark \text { The size and } \\
\text { density of the } \\
\text { microchannels } \\
\text { can be controlled } \\
\text { and predicted } \\
\text { with the } \\
\text { incorporation of } \\
\text { feedback } \\
\text { mechanism in } \\
\text { the RF-assisted } \\
\text { devices. }\end{array}$ & \\
\hline & $\begin{array}{l}\text { d) Calcitonin- } \\
\text { ViaDor }{ }^{\circledR} \text { system }\end{array}$ & $\begin{array}{l}\text { Syneron } \\
\text { Medical } \\
\text { Ltd., Israel }\end{array}$ & Calcitonin & Phase-I & Osteoarthritis & $\begin{array}{l}\checkmark \text { This technique } \\
\text { has been } \\
\text { demonstrated as }\end{array}$ & \\
\hline & $\begin{array}{l}\text { e) hPTH (1-34)- } \\
\text { ViaDor® system }\end{array}$ & TransPharma & $\begin{array}{l}\text { Synthetic human } \\
\text { parathyroid } \\
\text { hormone }\end{array}$ & Phase-I & Osteoporosis & $\begin{array}{l}\text { safe with } \\
\text { minimum } \\
\text { adverse effects } \\
\text { as only mild } \\
\text { erythema has } \\
\text { been reported. }\end{array}$ & \\
\hline \multirow[t]{3}{*}{$\begin{array}{l}\text { D. Laser } \\
\text { (commercial } \\
\text { products) }\end{array}$} & $\begin{array}{l}\text { a) P.L.E.A.S.E } \\
\text { technology }\end{array}$ & $\begin{array}{l}\text { Pantech } \\
\text { Biosolutio- } \\
\text { ns AG, } \\
\text { Ruggel, } \\
\text { Liechtenst- } \\
\text { ein } \\
\text { Norwood } \\
\text { Abbey, } \\
\text { Victoria, } \\
\text { Australia }\end{array}$ & ----- & ----- & ----- & $\begin{array}{l}\checkmark \text { This technique } \\
\text { (fractional beam) } \\
\text { provides large } \\
\text { diffusion area } \\
\text { due to ablation in } \\
\text { several small } \\
\text { areas at a specific } \\
\text { depth in the } \\
\text { target area. }\end{array}$ & $\begin{array}{l}\checkmark \text { The full beam } \\
\text { damages the } \\
\text { entire targeted } \\
\text { area. }\end{array}$ \\
\hline & $\begin{array}{l}\text { b) Epiture } \\
\text { Easytouch }^{\mathrm{TM}}\end{array}$ & & ----- & ----- & ----- & $\begin{array}{l}\checkmark \text { The ablated skin } \\
\text { heals very fast } \\
\text { compared with } \\
\text { other techniques. }\end{array}$ & $\begin{array}{l}\checkmark \text { Photothermic } \\
\text { mechanism leads } \\
\text { to increase in } \\
\text { temperature of } \\
\text { the skin } \\
\text { surroundings } \\
\text { due to absorption } \\
\text { of laser by water } \\
\text { and other skin } \\
\text { component. }\end{array}$ \\
\hline & & & & & & $\begin{array}{l}\checkmark \text { Direct ablation } \\
\text { (Er:YAG) } \\
\text { resulted in } \\
\text { minimum } \\
\text { damage to the } \\
\text { surrounding } \\
\text { tissues. }\end{array}$ & $\begin{array}{l}\checkmark \text { The fractional } \\
\text { amount of } \\
\text { energy is being } \\
\text { absorbed by the } \\
\text { water in the skin } \\
\text { leading to energy } \\
\text { loss and } \\
\text { subsequently, } \\
\text { cauterization of } \\
\text { small vessels. }\end{array}$ \\
\hline
\end{tabular}


Table 1 (continued)

\begin{tabular}{|c|c|c|c|c|c|c|c|}
\hline $\begin{array}{l}\text { Thermal ablation } \\
\text { methods }\end{array}$ & $\begin{array}{l}\text { Commercial/pipeline } \\
\text { products }\end{array}$ & Company & Drug & $\begin{array}{l}\text { Phase } \\
\text { in } \\
\text { clinical } \\
\text { trials }\end{array}$ & Application & Advantages & Disadvantages \\
\hline & & & & & & $\begin{array}{l}\checkmark \text { Pressure waves } \\
\text { (mechanical } \\
\text { waves) can } \\
\text { reversibly } \\
\text { change the skin } \\
\text { barrier and } \\
\text { increase the } \\
\text { permeability } \\
\text { temporarily. }\end{array}$ & $\begin{array}{l}\checkmark \text { The recovery } \\
\text { process } \\
\text { photothermic } \\
\text { mechanism is } \\
\text { fast (within } \\
\text { minutes) that can } \\
\text { minimize the } \\
\text { diffusion of } \\
\text { drugs to the } \\
\text { epidermis } \\
\text { compared with } \\
\mathrm{CO}_{2} \text { and } \\
\text { Er:YAG lasers. }\end{array}$ \\
\hline
\end{tabular}

most often is iron oxide, which in the presence of initiator undergoes oxidation and thereby generates heat [60]. This concept was first used to improve TDD of local anaesthetics such as lidocaine [61]. Lidocaine was studied for its release from carboxymethyl cellulose matrix both at saturated and sub-saturated levels using chemically generated heat. In this study, the heat generation efficiency of both the initiators such as oxygen and water was compared using iron oxidation. A sharp temperature variation was observed for the water as initiator compared with slow and controlled oxidation induced by oxygen. Therefore, higher drug diffusion across the polymeric matrix resulted in case of water as initiator. It is believed to be the alteration of the structure of the membrane and formation of regenerated cellulose membrane contributed to the result. However, the increased thermodynamic activity of lidocaine or inherent molecular diffusion cannot be tuned down completely [60].

A FDA-approved commercial product Synera ${ }^{\circledR}$ (known as Rapydan ${ }^{\circledR}$ in Europe) from Nuvo Research Inc., Canada, employs Controlled Heat-Assisted Drug Delivery $\left(\mathrm{CHADD}^{\mathrm{TM}}\right)$ heating POD based on iron oxidation as source of heat energy [Fig. 4] [62]. The patch contains $70 \mathrm{mg}$ each of lidocaine and tetracaine, and iron powder as heat-generating chemical. A different strategy called Eutectic Mixture Local Anaesthetics (EMLA ${ }^{\circledR}$ )-based cream containing each 2.5\% of lidocaine and prilocaine was clinically compared with Synera ${ }^{\circledR}$. A double-blind, randomized study with 82 adult human volunteers was conducted, where the Synera ${ }^{\circledR}$ patch was placed on one anticubutal surface and the EMLA® cream on the other before a vascular access procedure. The EMLA ${ }^{\circledR}$ cream exhibited better local anaesthetics than the Synera ${ }^{\circledR}$ patch after 10,20 , and 30 min of application, when subjects were rated for pain intensity employing a 100-mm visual analogue scale (VAS) [63].

\section{Thermoporation-based thermal ablation}

Thermoporation or microporation is a method of creating aqueous pathways across the SC that increases permeability of active ingredients through the skin into systemic circulation. In this method, an array of metallic filaments is held in contact with the skin surface for short duration (Fig. 5). These filaments are heated due to the passage of electric current through them, which resulted in the localized decomposition and vaporization of the SC. This led to the formation of microchannels on the skin surface. Thereafter, application of transdermal formulation such as gels, creams, patches, or vaccines will result in the enhancement of permeation of incorporated drugs $[64,65]$. The advantage of microporation device is that it can eliminate the risk of blood-borne pathogen transmission due to the use of sterilizable and disposable metal filaments [66]. However, precaution must be taken since excess heat can damage the deeper tissue and even induce thermohaemolysis [67]. In addition, electric field limitations may be considered as the filaments of the device are connected electrically [57].

Park et al. [20] had made a thorough investigation on the effect of heat on model drug calcein permeability across the human cadaver epidermis. The ex vivo experiment was conducted using a Franz diffusion cell with temperature ranging from 100 to $315{ }^{\circ} \mathrm{C}$ and time ranging from $100 \mathrm{~ms}$ to $5 \mathrm{~s}$. It was observed that temperature had a strong influence on skin permeability, but not the duration of action. It was also observed that fewfold increase in TDD at temperature range of $100-150{ }^{\circ} \mathrm{C}$ (zone I), $1-2$ orders of magnitude increase in flux at $150-250{ }^{\circ} \mathrm{C}$ (zone II), and 3-orders of magnitude enhancement of flux beyond $300{ }^{\circ} \mathrm{C}$ (zone III). The skin permeability enhancement for zones I, II, and III was due to disorderness of lipid structure, disruption of keratin structure, and 
Fig. 4 Lidocaine/tetracaine patch with CHADD $^{\mathrm{TM}}$ technology (Synera $\left.{ }^{\circledR}\right)$ (modified from reference [57])

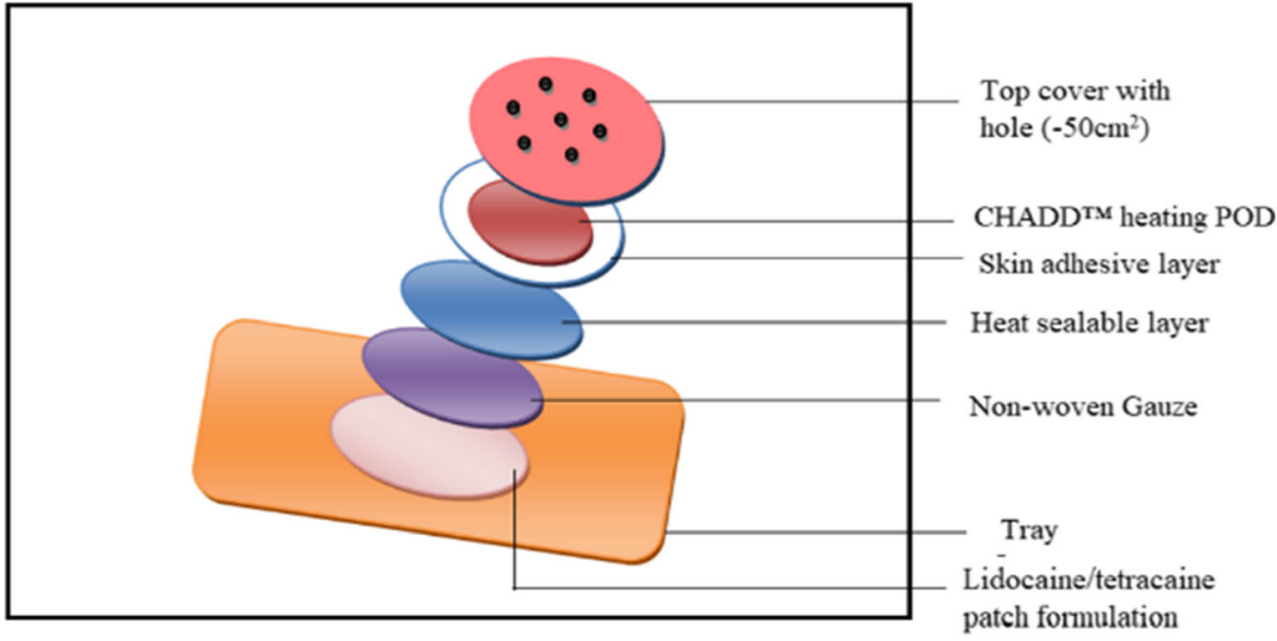

decomposition and vaporization of keratin, respectively. At optimum conditions, calcein transdermal delivery was found to increase by 760 -fold. In another study, Paranjape et al. [68] prepared an integrated patch composed of polydimethylsiloxane patch and micro-heaters for the transdermal delivery of glucose using human graft skin samples. They reported that an average temperature of $130^{\circ} \mathrm{C}$ for more than $33 \mathrm{~ms}$ is required to create micropores in the SC. These formed micropores were capable of diffusing biomolecules such as glucose across the skin [68].

\section{Commercial system}

Thermoporation technique uses controlled thermal energy which could enhance the influx of drugs into the skin. Microporation can be created by an FDA-approved device PassPort ${ }^{\mathrm{TM}}$ and Tixel which are discussed below.

\section{PassPort $^{\mathrm{TM}}$}

The Altea Therapeutics Corporation has made an important scientific and commercial breakthrough in the drug and vaccine delivery via the skin with its patented patch system, called PassPort $^{\mathrm{TM}}$ (Altea Therapeutics Corp., Atlanta, GA). This technology is based on the ablation of the SC by the application of heat to create aqueous micropores. The depth of the micropore/microchannels is reported to be $50-200 \mu \mathrm{m}$ in width and $30-50 \mu \mathrm{m}$ in depth. This system warrants the non-invasive, affordable, and controllable delivery of drugs of various therapeutic classes. The advantages of this system are that it can avoid the use of needles, pumps, and costly devices which are employed in other techniques $[56,69]$. In addition, a record of date and time of application of the patch by the patient is stored in the device [70]. Furthermore, the preclinical studies are conducted by Altea therapeutics on a wide range of molecules including parathyroid hormone, interferon- $\alpha$, and hepatitis B antigen $[23,71]$.

PassPort $^{\mathrm{TM}}$ is a re-usable thermal ablation device and consists of a handheld applicator, disposable porator microarray of tungsten wire which exerts short bursts of thermal energy and a patch (Fig. 6). Initially, the patch is coupled with an applicator and then the system is placed over the skin surface. The patch loaded applicator can be activated by simply pressing a button for a microsecond. Upon activation, the device passes electrical energy into microarray, which in turn is converted into thermal energy [71, 72]. This resulted to thermal energy creating microchannels in the SC and then the

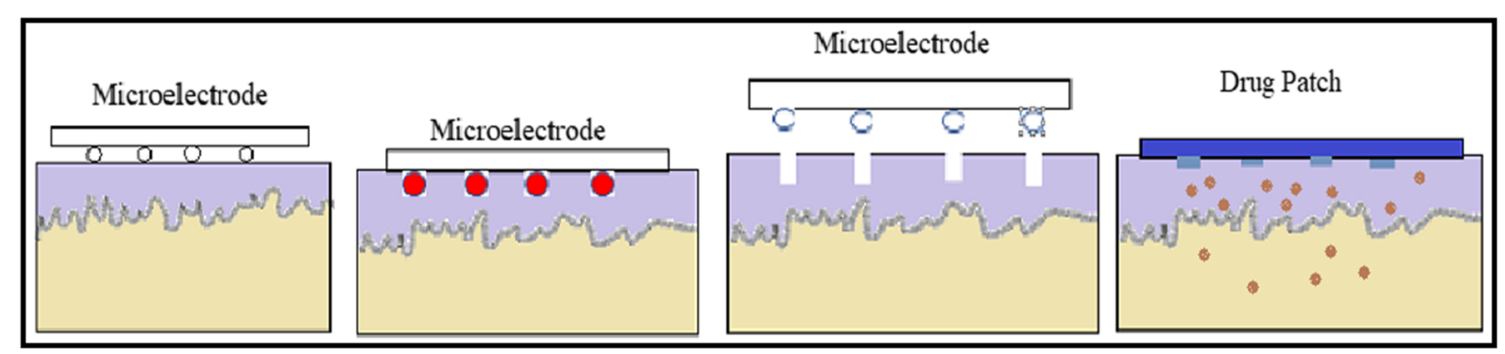

Fig. 5 Schematic representation of thermoporation. (a) Microelectrodes placed on skin, (b) microelectrodes traverse the skin and generated heat which ablated the skin, (c) micropores are formed and microelectrodes are removed, and (d) drug patch applied over the micropores to deliver the encapsulated drug (modified from references $[21,57]$ ) 
Fig. 6 Application of assembled PassPort ${ }^{\mathrm{TM}}$ system, consisting of applicator device, porator, and electrode array of tungsten

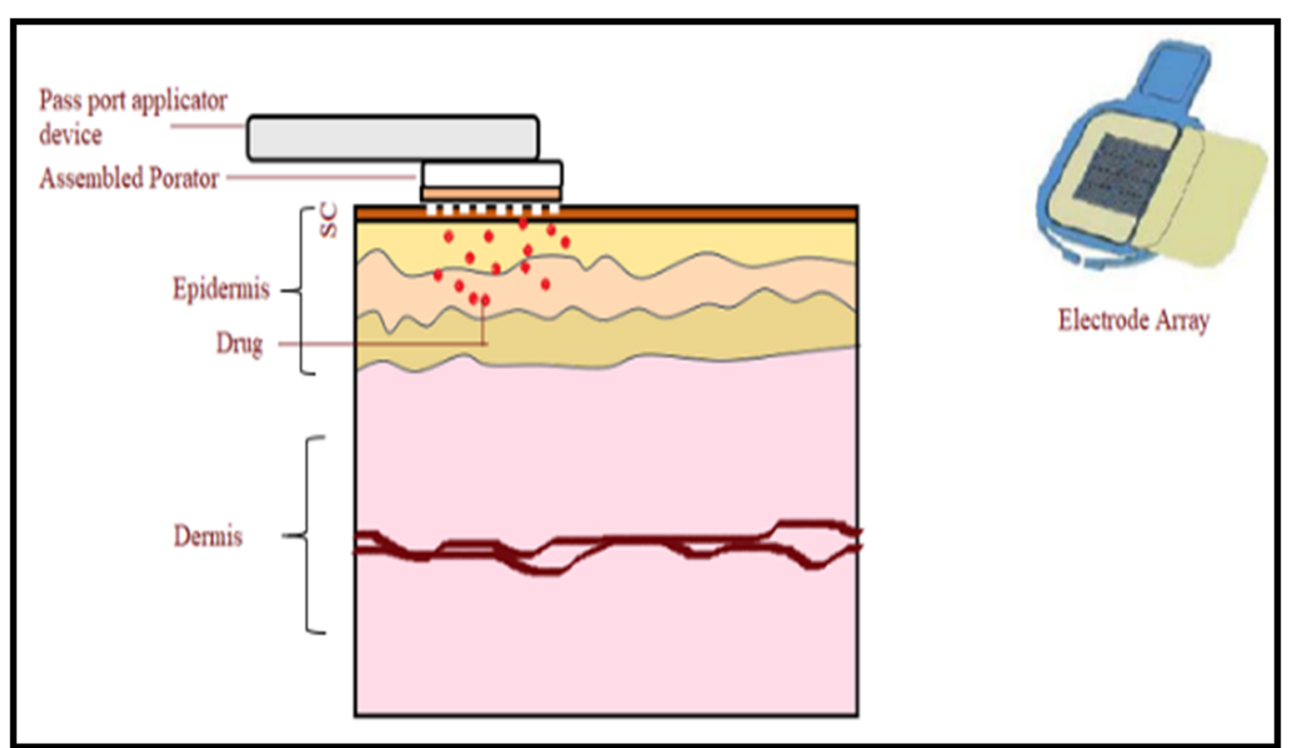

patch has to be placed over the microporated area [73, 74]. The thermal ablation patch possesses a surface area of $1 \mathrm{~cm}^{2}$.

Badker et al. [75] investigated the possibilities of delivering antiviral protein interferon alpha-2b (INFa2b) employing PassPort ${ }^{\mathrm{TM}}$ system with or without iontophoresis. The iontophoresis or passive transdermal delivery of INFa2b was not possible due to higher $\mathrm{MW}$ of $19.271 \mathrm{kDa}$. However, microporation method using PassPort ${ }^{\mathrm{TM}}$ system enables the delivery of INFa2b in vivo across hairless rats and the delivery was further improved, when both microporation and cathodal iontophoresis were employed simultaneously [75]. Delivery of recombinant $\mathrm{H} 5$ haemagglutinin vaccine via skin (intradermally) was successful in female mice, using PassPort $^{\mathrm{TM}}$ system against a pandemic influenza virus. The enhanced immunogenicity had protected the mice from the exposure to potential danger of the H5N1 influenza virus [65].
Tixel

Tixel is a thermo-mechanical device used for fractional ablation of the SC, which was developed by Novoxel, Landshut, Germany. It basically has three parts: (i) the tip, (ii) handpiece, and (iii) motor (Fig. 7). The tip's active surface comprised an array of $81(9 \times 9)$ tiny pyramid-shaped metallic pins with $1.23 \mathrm{~mm}$ of height and $100 \mu \mathrm{m}$ of radius at the apex. Each miniature pyramid has a base surface area of $3 \times 10^{4} \mathrm{~cm}^{2}$ that is available for contact with the skin. The tip is attached to a handpiece and connected to a linear motor. The back end of the tip is connected to a tiny ceramic heater in order to keep the tip at a constant temperature of $400{ }^{\circ} \mathrm{C}$ during the operation. The device sterilizes, validates, and cleans the tip automatically [76].

Its operation begins when the user places the handpiece flat on the skin and activates it. This leads to linear motor-driven advancement of the tip on to the skin surface at a predetermined 'protrusion' for a brief duration. During the

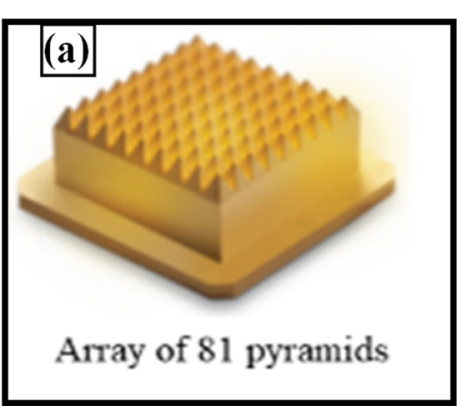

Fig. 7 Schematic diagram of Tixel. (a) Metallic tip. (b) Handpiece. (c) Schematic representation of tip in motion and protrusion of Tixel during operation (protrusion indicates to a distance of the pins beyond the gauge,
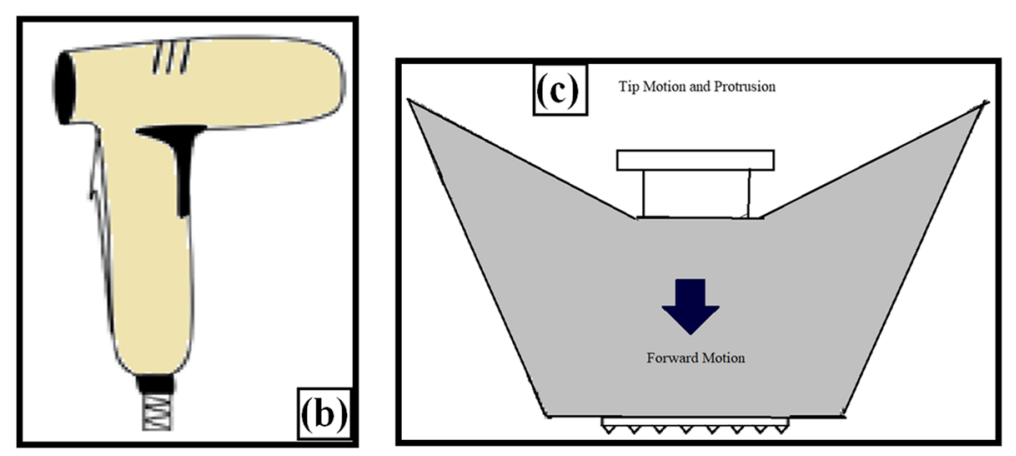

which is controlled to a desired length during tip motion operation) (modified from reference [76]) 
course of the tip motion, there is an uninterrupted supply of electrical energy to the heater and operations such as speed, temperature, and protrusion distance of the tip are active and precisely controlled. During the contact, thermal energy is transferred to the skin, resulting in the evaporation of the SC and formation of micropores. The time of contact between the tip and the skin is generally adjusted between 6 and $18 \mathrm{~ms}$, but more precisely, it should not be more than $9 \mathrm{~ms}$ as this time duration did not cause any skin necrosis or coagulation. The major advantage of Tixel is that it does not require a smoke evacuator and any protective eyewear for its operation [76].

Lee at al. [21] fabricated a thermal ablation device that has two major components: (i) microchamber which heats and ejects superheated steam and (ii) two masks which help in the transfer of energy from the device to the skin surface by acting as interface between the ejected superheated steam jet and the skin. They used two types of masks made up of titanium: (a) conductive mask used to allow the heat transfer without allowing the physical contact between steam and skin surface, and (b) window mask used to allow heat transfer to the skin through the windows/holes. They investigated permeability enhancement across full-thickness pig cadaver skin (ex vivo) of sulforhodamine B and bovine serum albumin (BSA) employing above device. The microdevice exhibited increase in skin permeability of 104-fold and 103-fold for sulforhodamine and BSA, respectively, when operated for $100 \mu \mathrm{s}$.

A study was undertaken to evaluate the influence of Tixel device on the permeability of three hydrophilic drug molecules such as verapamil $\mathrm{HCl}$, diclofenac sodium, and magnesium ascorbyl phosphate (a more stable prodrug of vitamin C). Permeability of the active ingredients across pig skin was performed in vitro employing Franz diffusion system. The operational conditions used are as follows: (i) temperature of $400{ }^{\circ} \mathrm{C}$, (ii) time period of $6 / 9 \mathrm{~ms}$, and (iii) protrusion of $400 \mathrm{~mm}$. They observed that verapamil $\mathrm{HCl}$ permeation at $24 \mathrm{~h}$ was increased from $17 \pm 6.1 \mu \mathrm{g} / \mathrm{cm}^{2}$ in case of untreated skin to $168.2 \pm 93.0 \mu \mathrm{g} / \mathrm{cm}^{2}$ (10-fold) and $382.6 \pm 196.8 \mu \mathrm{g} /$ $\mathrm{cm}^{2}$ (20-fold) in $6 \mathrm{~ms}$ and $9 \mathrm{~ms}$ for Tixel-treated skin, respectively. Similar patterns of drug permeation enhancement were observed for diclofenac (3-fold in $8 \mathrm{~ms}$ ) and ascorbyl phosphate ( 10 -fold in $8 \mathrm{~ms}$ ). They also reported that there was no significant collateral damage to the skin tissue and the absence of necrosis. In addition, the microchannels remained open and endured for at least $6 \mathrm{~h}$ after the treatment of Tixel [76].

\section{Radiofrequency-based thermal ablation}

$\mathrm{RF}$ is capable of forming micron-sized aqueous conduits in the $\mathrm{SC}$ and therefore it is considered as a promising technique which has wide applications in different fields such as electrosurgery, removal of malignant tissues, and in cosmetics for skin rejuvenation, skin tightening, and body contouring [77,
78]. RF-assisted thermal ablation involves the placement of an array of micro-electrodes directly onto the skin which is capable of generating an electric current into the skin in RF range of $100-500 \mathrm{kHz}[52,63,79]$. Exposure of the skin to high RF causes ionic vibration within the skin leading to generation of heat. This induced heat and causes liquid evaporation and ablation of the cells in that region of the epidermis. Depth of microchannels formed is limited to outer layers of the skin where blood vessels and nerve endings do not exist, thus reducing the pain and unpleasant sensation. The process is completed within few seconds and the microchannels are filled with interstitial fluid which possesses hydrophilic nature. Depending on the properties of microelectrodes, and the number and depth of the microchannels, the rate of drug delivery is controlled [26, 80, 81]. The RF-based ablation technique has many advantages, including (i) the microchannels are formed within milliseconds, (ii) it helps in delivery of wide range of drugs with hydrophilic nature and macromolecules, (iii) microchannels are capable of sustaining the drug release in order to maintain desired blood levels, and (iv) the size and density of the microchannels can be controlled and predicted with the incorporation of feedback mechanism in the RFassisted devices [81, 82]. A RF-assisted device is composed of the following: (i) the device, (ii) microelectrode array (100 microelectrodes $/ \mathrm{cm}^{2}$ ), and (iii) patch containing active ingredients.

\section{Commercial product}

RF-based thermal ablative device available commercially is the ViaDerm ${ }^{\circledR}$ device.

\section{ViaDerm $^{\circledast}$ system}

The ViaDerm ${ }^{\circledR}$ system (now known as ViaDor ${ }^{\circledR}$ ) was developed by TransPharma Medical ${ }^{\mathrm{TM}}$ Ltd. (Lod, Israel), which has now been acquired by Syneron Medical (Yokneam, Israel). ViaDor ${ }^{\circledR} \mathrm{RF}$ is a self-administrable device that has been evaluated for the delivery of various hydrophilic compounds, peptides, and genes across the skin [77, 83, 84]. The components of the ViaDor® system include a reusable handheld batteryoperated electronic controller, disposable microelectrode array having an electrode density of 100-200 microelectrodes/ $\mathrm{cm}^{2}$, and a patch loaded with the drug. Each electrode receives a burst of energy as per the program set and generates vibration motion leading to localized heating. This heating creates microchannels in the skin and prepares the site for application of the transdermal formulations such as patch. The device is available in three different sizes (with treatment area of 1, 2.5, or $5 \mathrm{~cm}^{2}$ depending on the dose to be delivered [71, 80,82].

This technique has been demonstrated as safe with minimum adverse effects. For instance, only mild erythema has been reported. However, skin damage of serious nature may 
happen; when there is no appropriate contact between the applicator and tissue, the applicator is lifted. However, advancement in the technique along with the development of new computerized circuit made the process of application safe by immediately switching the device off when there is any sense of energy impedance [56]. Another advantage of this technique is that it requires minimum operator training for the use of the device.

\section{Patch technology for protein delivery}

Thus far, there is no reported commercial technology which can incorporate proteins into transdermal patches. However, transdermal delivery of proteins is made possible by using the TransPharma MedicalTM Ltd.'s unique printed patch technology after treating the skin with the ViaDor ${ }^{\circledR}$. The drug is loaded into the patch in a dry state and is delivered into the previously formed microchannels. It is assumed that the highly water-soluble protein delivered into the microchannels is dissolved in interstitial fluid present in the microchannels leading to higher concentration of proteins in situ. Due to the existence of higher concentration gradient, the dissolved protein molecules transported to the viable epidermis of the skin which resulted in peak drug blood profile.

To manufacture a protein patch, the TransPharma Medical $^{\mathrm{TM}}$ Ltd. has adapted a unique manufacturing dispensing technology. It involves three steps: (i) preparation of aqueous protein solution with buffer and stabilizer such as mannitol, sucrose, and trehalose, (ii) resulted solution is dispensed dropwise on to a non-adhesive liner, and (iii) drying of solution drops using stream of air/nitrogen to obtain protein patch. In this technique, the patch size and shape, drug load on the patch, and yield can easily be controlled [80, 82]. The preparation process does not involve addition of hydrophobic solvents or heating; thus, it is termed as an "environment friendly" manufacturing process. Furthermore, the drug loss during manufacturing is minimum and the process is capable of preserving the biological activity of proteins [77].

There are many researchers who used the ViaDor ${ }^{\circledR}$ system to ablate the SC and then applied various topical and transdermal formulations in order to enhance permeation of active ingredients across the skin. In this context, an investigation was carried out to enhance the permeability of two model drugs such as diclofenac sodium and granisetron $\mathrm{HCl}$ across full-thickness porcine ear skin in vitro and abdominal rat skin in vivo using double pre-treatment of the ViaDor ${ }^{\circledR}$ system containing 100 microelectrodes $/ \mathrm{cm}^{2}$. The result showed that there was approximately 8 -fold and 30 -fold increase in diclofenac sodium and granisetron $\mathrm{HCl}$ plasma concentration after $6 \mathrm{~h}$ and $24 \mathrm{~h}$ of study, respectively, compared with passive diffusion [85]. Levin et al. [83] studied the influence of the RF-ablated skin on the permeation enhancement of human growth hormone across skins of rat and guinea pig in vivo.
They observed $75 \%$ increase in bioavailability of hGH in rat model, whereas $33 \%$ increase of bioavailability in guinea pig, and compared subcutaneous injections. In addition, they also observed elevated levels of systemic insulin-like growth factor-1 indicating the bioactivity of hGH when administered transdermally.

The ViaDor® system has huge potential in delivering macromolecules and gene therapy vectors to the skin as their delivery can be controlled and targeted to the viable epidermis. Birchall et al. [84] successfully augmented the gene delivery and expression of a $\beta$-galactosidase reporter plasmid DNA applied to ViaDor ${ }^{\mathrm{TM}}$ (with $50 \mu \mathrm{m}$ electrode arrays) treated full-thickness human breast skin. Furthermore, the intensity and extent of gene expression were found to be better when DNA formulation was applied prior to the application of ViaDor $^{\mathrm{TM}}$. The delivery of another hydrophilic macromolecule complex testosterone-cyclodextrin $(\sim 2.5 \mathrm{kDa})$ across excised pig skin in vitro and hairless guinea pigs in vivo was studied. The in vitro permeation study across the skin was enhanced by 70 -fold compared with control and the in vivo delivery was found to be extended up to $24 \mathrm{~h}$ post device application. The natural recovery occurs after $24 \mathrm{~h}$, which was confirmed by the measured value of transepidermal water loss [86].

Factors influencing drug delivery through the RF-assisted microchannels are as follows: (i) molecular size of drug, (ii) solubility of drug in water, (iii) concentration of drug, (iv) microchannel density, (v) duration of drug delivery, (vi) dosage form of the drug, (vii) types of patches, and (viii) drug profile [77, 80, 82].

\section{Laser thermal ablation}

A typical medical laser used for thermal ablation comprised three parts: (i) pump source, (ii) lasing material, and (iii) optical cavity. These components govern the characteristics such as wavelength and energy of a laser device [87]. The operation of a laser device starts with the supply of input energy from pump source to lasing material, which excites most of its electrons to higher energy level. The movement of electrons from the excited state to the ground state induces the release of energy in the form of photons of light. These emitted photons produce optical activity because of their reflection between the reflectors, and this amplified light transmitted through the partial reflector is termed as laser light [88].

There are two laser conformations such as full beam and fractional beam based on the structure of laser beam. The former type of beam damages the entire targeted area, whereas the later one damages several small areas at a specific depth in the targeted area. Therefore, the fractional beam has advantages of the large diffusion area and heals very fast compared with full beam $[89,90]$. There are three possible mechanisms with which the laser beam shall interact with the surface 
irradiated such as photothermolysis, direct ablation, and mechanical waves [91].

Photothermic mechanism works on the principle of absorption of the laser radiation by water or other skin components resulting in the increase in temperature of the surrounding skin. This leads to small skin burns or ablation. The major proponent of this type of interaction is $\mathrm{CO}_{2}$ laser (wavelength of $10,600 \mathrm{~nm}$ ) and the mechanism involved is based on the vaporization and ablation [92]. The main disadvantage of this type of laser is that the fractional amount of energy is being absorbed by the water in the skin leading to energy loss. In addition, it leads to cauterization of small vessels; however, large blood vessels are not affected [93]. In case of direct ablation-assisted drug delivery, the interaction of the laser radiation with the skin resulted in the breakup and expulsion of skin parts at supersonic speeds. The foremost exponent for direct ablation is erbium-doped yttrium aluminium garnet (Er:YAG) lasing material-based laser. Compared with $\mathrm{CO}_{2}$ laser, Er:YAG laser emits radiation of higher wavelength $(2936 \mathrm{~nm})$. The prominent advantage of this is that maximum energy (12-18-fold higher than $\mathrm{CO}_{2}$ laser) of the radiation is absorbed by water available in the skin. The transition of energy is described as photomechanical that creates micropores by microexplosions of water molecules present in the skin. This resulted in minimum damage to the surrounding tissues [88]. This is the reason why Er:YAG laser is most often used in the cutaneous drug delivery. The third mechanism involves the generation of mechanical waves to enhance TDD. The mechanical waves are generated either by direct irradiation of material in contact with the skin by the beam of laser light or confined irradiation due to overlay present at the top of irradiated material [91, 94]. The pressure waves generated create transient pores within the SC lipids by expanding the lacular spaces within the intercellular regions of the SC without inflicting ablation. Therefore, this method is also considered as non-invasive mechanism. The potential advantage of pressure waves is that they can reversibly change the skin barrier and increase the permeability temporarily. However, the recovery process is fast (within minutes) that it can minimize the diffusion of drugs to the epidermis compared with $\mathrm{CO}_{2}$ and Er:YAG lasers. The irradiated materials used are metallic films such as sole metal (e.g. aluminium, lead, gold), composites (e.g. epoxy resin and graphite powder plastic film with aluminium), and bilayer film of polyvinyl chloride and gold. The function of these materials is to convert light energy to pressure energy [89].

There are four different phases in laser-based ablation such as heating of the skin $\left(37-60^{\circ} \mathrm{C}\right)$, coagulation $\left(60-65^{\circ} \mathrm{C}\right)$, drying $\left(90-100{ }^{\circ} \mathrm{C}\right)$, and finally, vaporization $\left(>100{ }^{\circ} \mathrm{C}\right)$ [95]. The degree at which the SC layer disrupted is controlled by many parameters such as wavelength, tissue thickness, pulse energy, length, number and repetition rate, tissue absorption coefficient, and the duration of laser exposure.
Several types of lasers with broad wavelengths are tested but very few can be applied transdermally to deliver the drugs causing little tissue damage. Lasers are divided into two types: non-ablative and ablative. Both are utilized for enhancing the transdermal permeation of drugs [96]. The example of the former class is Ruby lasers, which showed no/negligible damage to the skin. However, partial or complete removal of the $\mathrm{SC}$ occurs in the latter case and the examples are $\mathrm{CO}_{2}$ and Er: YAG laser [97]. The details about the two types of lasers are mentioned in Table 2.

Ablative lasers are used to enhance the absorption of drugs across the skin of diverse therapeutic classes. Among them, analgesics of opioid class and non-steroidal anti-inflammatory drugs were investigated to a large extent compared with other classes of drugs. Lee et al. [100] investigated the feasibility of employing Er:YAG laser to enhance and control transdermal delivery of opioid analgesics such as morphine, nalbuphine, and buprenorphine. Their oral administration suffers due to low oral bioavailability and short half-lives. Therefore, an in vitro permeation experiment was performed across lasertreated pig skin to enhance their permeation. There was 10- to 35-fold of permeation enhancement of above drugs depending on the fluence (energy applied per unit area) ranging from 1.7 to $2.6 \mathrm{~J} / \mathrm{cm}^{2}$ and physicochemical properties such as lipophilicity and MW. Due to higher MW and lipophilicity, buprenorphine exhibited lesser skin permeability compared with morphine and nalbuphine. In another study, transdermal flux of nalbuphine was increased by 73 -fold, when Er:YAG laser was used (fluence between 0.9 and $17.5 \mathrm{~J} / \mathrm{cm}^{2}$ ) compared with non-treated group. Indomethacin has same MW of $357 \mathrm{Da}$ as nalbuphine, but its transdermal flux improved by 7.5 -fold using laser ablation with same fluence. This result was attributed to the difference in $\log P$ value with higher value for Indomethacin ( $\log P$ of 4.2) compared with nalbuphine ( $\log P$ of 0.2$)$ [101].

Lee et al. [96] conducted an in vitro permeation study to deliver 5-fluorouracil transdermally across full-thickness skin of female nude mice employing 3 lasers such as ruby, Er:YAG, and $\mathrm{CO}_{2}$. The permeation of 5-fluorouracil was moderately increased through the skin by single-pulse photomechanical wave generated by a ruby laser (at 4.0 and $7.0 \mathrm{j} / \mathrm{cm}^{2}$ ), without severely affecting the structure of the skin. Er:YAG laser partially ablates the $\mathrm{SC}$ and increases the flux of 5-fluorouracil by 53- to 133-fold higher than that of intact skin. This is attributed to the combination of the SC ablation and thermal effect. However, lower energies of $\mathrm{CO}_{2}$ laser were unable to modulate permeation of 5-fluorouracil, but higher fluences ( 4.0 and $7.0 \mathrm{~J} / \mathrm{cm}^{2}$ ) increased the flux from 36- to 41-fold. In an interesting investigation, Gomez et al. [102] examined permeation enhancement ability of neodymium-doped yttrium aluminium garnet (Nd:YAG) laser on in vitro transdermal delivery of 5fluorouracil across pinna skin of the inner side of rabbit ear. $\mathrm{Nd}$ :YAG laser at $355 \mathrm{~nm}$ was used in in vitro study and the 
Table 2 Lasers used in delivery of drug through transdermal route $[96,98,99]$

\begin{tabular}{llll}
\hline Laser type & Wavelength $(\mathrm{nm})$ & Pulse duration & Role in transdermal delivery \\
\hline Ruby & 694 & $25-40 \mathrm{~ns}$ & Permeabilization of SC \\
$\mathrm{CO}_{2}$ laser & 10,600 & $50 \mathrm{~ms}$ & Ablation via vaporization \\
Er: YAG & 2940 & $250-400 \mu \mathrm{m}$ & Ablation via vaporization \\
\hline
\end{tabular}

result showed that the enhancement ratio for drug permeation was increased from 2.36 to 429 , with increasing the fluence from 0.3 to $2 \mathrm{~J} / \mathrm{cm}^{2}$. The $\mathrm{Nd}: Y A G$ laser was found to remove the SC and some viable epidermal layers as well. In another study Liu et al. [103], two output modes of Nd:YAG laser at $1064 \mathrm{~nm}$ such as long-pulsed $(15 \mathrm{~J} / \mathrm{cm} 2)$ and Q-switched $\left(0.5 \mathrm{~J} / \mathrm{cm}^{2}\right)$ for permeation of glycerol across Wistar rat skin were compared. The results demonstrated similar glycerol permeation-enhancing capacity possessed by both the modes. The long-pulsed irradiation made corneocytes fragile and exfoliative by increasing the skin temperature and loosened keratin. However, Q-switched mode completely disrupted corneocytes and keratin, thereby enhancing the glycerol permeation.

Topical delivery of DNA and transdermal delivery of protein and peptides seem to be attractive for the prevention and treatment of skin as well as systemic diseases. However, this delivery method is limited by the impervious SC layer of skin. In order to circumvent this barrier, Lee et al. [104] employed Er:YAG laser to enhance the delivery and expression of antisense oligonucleotides and DNA in the skin of nude mice. In vitro permeation study resulted in the 3 - to 35 -fold increase in antisense oligonucleotides permeation in case of ablated skin compared with the untreated skin. The permeation was found to depend on the fluence of laser and molecular mass of antisense oligonucleotides. DNA expression was found to be 160-fold superior for ablated skin than that of intact skin. In another study, peptides and related vaccine (lysozyme antigen) were delivered transdermally with Er:YAG laser. It was observed that there is 3 - to 140 -fold increase in peptide permeation across the partly ablated skin of nude mouse/hairy mouse compared with untreated skin in vitro. The other factors that played important role in permeation enhancement were molecular size (peptides with a larger molecular size demonstrated higher enhancement compared with the smaller counterpart), lipophilicity, and sequence of peptides. It was also observed that laser treatment alone (no adjuvant or penetration enhancer) significantly enhanced (3-fold) production of antibodies in the serum, after in vivo skin vaccination of lysozymes [105].

Lee et al. [106] investigated the in vitro permeation enhancement of magnesium ascorbyl phosphate across nude mouse skin employing laser techniques (Er:YAG and $\mathrm{CO}_{2}$ lasers) and microdermabrasion (SC stripping). They observed that Er:YAG laser greatly enhanced vitamin $\mathrm{C}$ permeation with 86.04- to 260.86-fold increase and skin deposition of the drug with 71.56- to 123.22-fold enhancement compared with intact skin. In case of $\mathrm{CO}_{2}$ laser, there is an 8.19-fold increase in vitamin $\mathrm{C}$ flux at lower fluence $\left(1.4 \mathrm{~J} / \mathrm{cm}^{2}\right)$, which could not ablate any of the SC or epidermal layers. However, at higher fluences such as 4.0 and $7.0 \mathrm{~J} / \mathrm{cm}^{2}$, the SC layer was sufficiently ablated. Enhancement of flux is lower in case of $\mathrm{CO}_{2}$ laser compared with Er:YAG, which is due to skin tightening by $\mathrm{CO}_{2}$ laser. Microdermabrasion ablates a portion of the SC layer, thereby moderately enhancing skin permeation and deposition of vitamin $C$ [107]. In another study, Hsiao et al. [107] investigated the influence of both Er:YAG and $\mathrm{CO}_{2}$ lasers on the permeation enhancement of two vitamin $\mathrm{C}$ derivatives such as ascorbic acid 2-glucoside (AA2G) and 3O-ethyl ascorbic acid (EAC) across the skin of female nude mouse (Balb/c-nu strain) in vitro. The flux of AA2G and EAC across the Er:YAG laser (with fluence ranging from 2.5 to $6.3 \mathrm{~J} / \mathrm{cm}^{2}$ )-treated skin showed 35 - to 78 -fold and 105 - to 189-fold increase, respectively, compared with flux across intact skin. In case of $\mathrm{CO}_{2}$ laser-treated skin at $5 \mathrm{~W}$, the flux enhancement was found to be 82-fold and 181-fold for AA2G and EAC, respectively, than their flux across untreated skin [108].

Lee et al. [108] studied the release of doxorubicin from hollow gold nanocells in a near-infrared-induced ablated skin. In vivo study was conducted using female Sprague-Dawley nude mice. Histological investigation demonstrated that combination of laser and intratumoral injection showed maximum tumour necrosis compared with treatment without laser. The photoaccoustic imaging revealed the increase in temperature of tumour cell from 37 to $50{ }^{\circ} \mathrm{C}$. Thus, combination of laser and nanoparticles loaded with doxorubicin has huge potential for the local anticancer therapy. Imiquimod, a receptor-7 agonist, is used to treat external genital and perianal warts, and actinic keratosis (consistent with squamous cell carcinoma histological) by boosting cutaneous immune response. In vitro study was conducted employing excised porcine dorsal skin or nude mouse using Franz diffusion cell and in vivo study was performed by applying imiquimod over pre-treated dorsal skin of nude mice. Imiquimod flux was found to be increased both in vitro and in vivo with Er:YAG laser treatment. It was observed that a concentration of $0.4 \%$ from an aqueous vehicle in combination with laser treatment produces approximately same flux as commercial cream with $5 \%$ of imiquimod dose without laser treatment. It was also observed 
that by increasing the fluencies from 2 to $3 \mathrm{~J} / \mathrm{cm}^{2}$, the drug flux was found to be increased from 46-fold to 127-fold [109]. Transdermal delivery of 5-aminolevulinic acid was envisaged with laser (Er:YAG and Nd:YAG)-assisted method in order to avoid its poor permeability across intact skin. The drug permeation was found to be increased in laser-ablated skin and the highest flux enhancement of 200.3-fold was observed for the laser wavelength of $2940 \mathrm{~nm}$ and fluence of $1.6 \mathrm{~J} / \mathrm{cm}^{2}$ compared with laser-untreated skin [110]. Presently, small interfering RNA (siRNA)-based therapy is being widely used to treat various heritable skin disorders such as actinic dermatitis, actinic keratosis, and skin cancer. However, its treatment through topical route suffers due to rigid barrier of the SC. To overcome this known hindrance, Lee et al. [111] employed Er:YAG and $\mathrm{CO}_{2}$ lasers to investigate permeation enhancement of siRNA in vitro using full-thickness skin of nude mouse and in vivo using nude mouse. They reported an 11fold and 12-fold increase in fluxes of siRNA for Er:YAG and $\mathrm{CO}_{2}$ laser, respectively, compared with laser-untreated skin. They also reported that hair follicles are the major drug deposition areas for laser-treated skin.

Lee et al. [112] employed fractional $\mathrm{CO}_{2}$ laser to investigate in vitro permeation enhancement of small molecules as well as macromolecules using fluorescein isothiocyanatelabelled dextran as model drug at four different MW such as $4,10,20$, and $40 \mathrm{kDa}$ across excised and dermatomed porcine skin. They observed that in employing fractional $\mathrm{CO}_{2}$ laser, it is possible to improve the skin permeation enhancement of compounds of diverse MW.

\section{Commercial product}

Initially, laser ablation technique is expensive and particularly restricted to hospitals but the development of handheld devices made it possible to ablate the SC by avoiding pain. Currently, the laser ablation-based systems available in the market are as follows: (i) Painless Laser Epidermal System (P.L.E.A.S.E. () technology developed by Pantech Biosolutions AG (Ruggel, Liechtenstein), and (ii) Epiture EasytouchTM developed by Norwood Abbey (Victoria, Australia).

\section{P.L.E.A.S.E. ${ }^{\oplus}$ technology}

P.L.E.A.S.E.® technology uses Er:YAG laser which emits light at $2940 \mathrm{~nm}$ and facilitates its absorption by water molecules. The excitation of molecules leads to the formation of pores by heat generation and evaporation at the site of application in epidermis and allows minimum heat to surrounding tissues $[85,91]$. The diameter of pores ranges from 50 to $200 \mu \mathrm{m}$ and the depth is controlled by the application of low-energy lasers where conventional Er:YAG laser forms micropores of 7 -mm depth. P.L.E.A.S.E. ${ }^{\circledR}$ is the most convenient and safe device which painlessly delivers the drugs, and is able to control the size and depth of pores [99]. The P.L.E.A.S.E. ${ }^{\circledR}$ device is the latest technology which assists in the delivery of large molecules and bioactive agents through the skin $[113,114]$. Step-wise process of using P.L.E.A.S.E. ${ }^{\circledR}$ device is mentioned as follows $[114,115]$ :

i. Before the poration process, the licenced medical personnel fixes the parameters needed for the therapeutic delivery of applied drug patch.

ii. The device with a disposable tip is pressed on to the application site by pressing the on button. It creates micropores with a depth of $1 / 10 \mathrm{~mm}$.

iii. The formulations such as patch/gel/cream-containing drugs are applied on the microporated skin sample. Thereafter, the incorporated drug is delivered into systemic circulation via micropores.

Safety profile demonstrated that P.L.E.A.S.E.® enables painless delivery through the skin and no infections were reported in clinical settings. In addition, no pigmentation and texture changes were observed in a 3-month study period. Preclinical studies reported so far described its utilization in the delivery of diabetes, pain, and vaccines.

\section{EPIMMUM $^{\text {TM }}$ patch}

EPIMMUM $^{\mathrm{TM}}$ is a process which uses P.L.E.A.S.E. ${ }^{\circledR}$ device to deliver immunogen via laser-microporated skin (Fig. 8). The laser microporation creates an inflammatory stimulus and boosts immune response. This technology assists in painless delivery of immunogen to targeted skin layers. It aids in delivery of huge vaccine market for treatment of various diseases like cancer, allergy, infectious diseases, autoimmune diseases, and Alzheimer's. These patches are having many advantages:

- Suitable to use in paediatric patients as it is painless and needle free.

- Easy to use and fast application is possible.

- Negligible contamination.

- Reproducible when compared with microneedles.

- Immunogenicity is improved when compared with delivery through subcutaneous or intramuscular route.

- Inexpensive compared with syringe cost.

Bachhav et al. [116] determine the influence of pore number and depth on the rate and extent of lidocaine delivery across porcine ear skin as model membrane. There are statistically significant differences in the cumulative skin permeation of lidocaine between 0 (control, without porated skin) and 150 pores with that of higher porated skin $(300,450$, and 
Fig. 8 Functioning of EPIMMUM $^{\mathrm{TM}}$ patch. (i) Formation of micropores using P.L.E.A.S.E. ${ }^{\circledR}$ and (ii) application of patch to deliver immunogen
Laser microporation

\section{Occulsive backing}
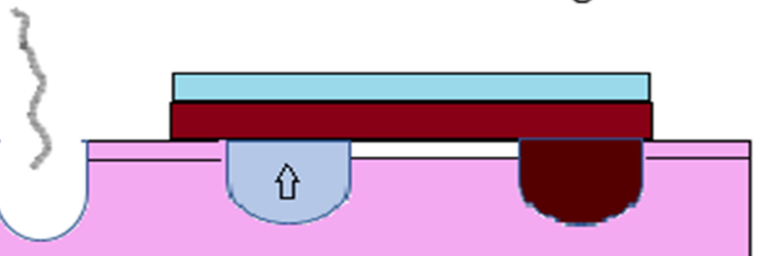

transepidermal water loss
Antigen diffusion
900 pores). However, cumulative permeation of lidocaine between higher porated skin was statistically insignificant, which may be due to the delivery of $>50 \%$ of applied dose. Similarly, swallow pores (selective removal of $20-30 \mu \mathrm{m}, 60$ $100 \mu \mathrm{m}$, and $>150-200 \mu \mathrm{m}$ of SC) did not exhibit any statistical significance in cumulative permeation of lidocaine across the skin. They concluded that P.L.E.A.S.E. ${ }^{\circledR}$ has the ability to create well-defined pores of size $(150-200 \mu \mathrm{m})$ in the skin and is able to enhance both the rate and extent of lidocaine permeation. However, Yu et al. [117] reported there is significant increase in prednisolone deposition and permeation across ear skin of mice with the increase in number of pores and fluence created by P.L.E.A.S.E. $®$ device. It was observed that a 4 -fold increase in pore numbers (450 to 1800) demonstrated more than 3-fold increase in drug permeation and deposition (60.85 \pm 14.05 to $197.18 \pm 29.62 \mu \mathrm{g} / \mathrm{cm}^{2}$ ). Likewise, approximately 3 -fold increase in prednisolone delivery $(47.54 \pm 4.90$ to $135.59 \pm 6.85 \mu \mathrm{g} / \mathrm{cm}^{2}$ ) was witnessed with 2-fold increase in fluence ( 22.65 to $45.3 \mathrm{~J} / \mathrm{cm}^{2}$ ). In another study, Bachhav et al. [118] reported a significant increase in diclofenac delivery across porcine skin in vitro with increase in number of micropores created and fluency used employing P.L.E.A.S.E.® device. For instance, increasing number of pores $(50-80 \mu \mathrm{m})$ from 150 to 900 leads to increase in diclofenac delivery from 3.7-fold to 13 -fold enhancement compared with laseruntreated skin. Likewise, there was more than 3-fold increase in permeation of drug with 6-fold increase in fluency. Diclofenac delivery from marketed gel (Solaraze ${ }^{\mathrm{TM}}$ ) also found to be increased across laser-porated skin compared with untreated skin of mice. They also observed that there was statistical equivalent in the case of the human skin [118]. Puri et al. [119] made a comparative permeation study of 3fluoroamphetamine $\mathrm{HCl}$ across dermatomed human skin in vitro employing passive, chemical technique using oleic acid as penetration enhancer and physical technique such as microneedle, laser, and iontophoresis. Compared with passive method, there were 508-fold and 548-fold increase in drug permeation for laser-treated microporated skin and anodal iontophoresis, respectively. In addition, ablative laser technique showed minimum lag time and thereby exhibiting faster onset of action. Due to short half-life, low oral bioavailability, and several systemic adverse effects caused by oral administration of pentoxifylline, an attempt was made to administer it through cutaneous route on a P.L.E.A.S.E.treated skin for the treatment of peripheral arterial diseases. Intact as well as porated fresh porcine ear skin was used as model membrane. It was observed that poly(lactide-coglycolide)-based microparticles contain the drug deposited in the micropores and serve as an intraepidermal depot that ensures sustained drug release without repeated microporation as well as after the closer of micropores [120].

Vaccines may be delivered through intramuscular, subcutaneous, or cutaneous routes. Out of them, cutaneous route is considered to be more effective based on its profuseness in targeting antigens and immunocomponent cells. But the presence of the SC layer on the surface of the skin makes the cutaneous immunization challenging. In this context, creation of micropores in the SC with laser ablation method and then transcutaneous immunization (TCI) seems to be the best option. This is because TCI using fractional laser-based ablation will allow vaccination in a defined, painless, and reproducible manner. Weiss et al. [121] studied the possible induction of immune response through transcutaneous route using P.L.E.A.S.E. ${ }^{\circledR}$ device and then compared with immunization through subcutaneous route using dermatomed porcine ear skin in vitro and female mouse (Balb/c and C57BL/6) in vivo. They reported that the formation of precise micropores of defined number and depth induced high levels of antigen uptake. In addition, the generation of immune responses was equal or higher compared with those induced by subcutaneous injection of antigen. In another study, 
hepatitis B surface antigen (HBsAg) was successfully administered through the skin of female mouse $(\mathrm{Balb} / \mathrm{c})$ in vivo employing TCI with microporation. The laser (P.L.E.A.S.E.® device) was used to fractionally ablate the SC. The factors such as pore number, fluence, and adjuvants played a major role in the immunization process. It was observed that the optimized HBsAg induced similar antibody titers compared with intramuscular injection of HBsAg [122].

The success and the safety of laser technology mainly depend on skin recovery. In this context, Lee et al. [97] investigated the mice skin recovery after the application of Er:YAG laser and $\mathrm{CO}_{2}$ laser for 7 days. After laser treatment, biopsy specimens were collected from day one to day seven and treated with haematoxylin and eosin followed by sectioning. Then, these sections were visualized under a microscope. The results demonstrated that the pores created due to the application of Er:YAG laser created were recovered in 4 days. However, the skin samples treated with $\mathrm{CO}_{2}$ laser required 5 days to recover to its normal state.

\section{Epiture easy touch ${ }^{\mathrm{Tm}}$}

Epiture easy touch ${ }^{\mathrm{TM}}$ device uses Er:YAG laser with a 3.6 V DC rechargeable batteries. It is a hand-held portable device approved by the US and Australian regulatory bodies for the administration of locally applied anaesthetics. It has the advantage of avoiding damage to deeper skin tissues and employed to perform clinical trials for the delivery of local anaesthetics [114]. Epiture easy touch ${ }^{\mathrm{TM}}$ device is beneficial in delivery of over the counter lidocaine (4\%) resulted in dermal anaesthesia in 5 min [123]. Table 3 summarizes various thermal ablation techniques with devices used to enhance drug permeation across skin and their obtained results. A list of patents approved is presented in Table 4 .

\section{Side effects/safety related to thermal ablation}

Safety and tolerability are evaluated on the basis of the frequency of adverse events that occur after the application of formulation on the thermally ablated skin. The measurement is based on the presence of oedema and erythema, and results are quantified using the Draize irritation index for irritation and erythema on a scale of $0-8$ and VAS for pain on a scale of $0-100$. The Draize index and VAS score were found to be 0.75 and 5 , respectively, indicating occurrence of erythema and pain to less extent. Slight erythema was reported for the use of prototype for PassPort ${ }^{\mathrm{TM}}$ system [75]. Likewise, the application of lidocaine/tetracaine patch (Synera ${ }^{\mathrm{TM}}$ ) resulted in most common adverse events such as erythema, blanching, and oedema in multiple clinical trials [63].

Among three lasers employed, ruby laser did not produce any observable disruption in the skin structure, indicating ruby laser is safe for the enhancement of drug permeation across skin. However, Er:YAG or CO2 laser necessitates 3-5 days of the recovery of the SC barrier function after radiation and complete recovery is not observed until 7 days. The skin recovery is measured in terms of increased SC thickness towards normal. In addition to the ablation effect on the SC thickness, $\mathrm{CO}_{2}$ laser also develops thermal injury to the skin, which brings about more severe structural changes in the skin [97]. More recently developed ablative fractional laser demonstrated dramatic skin barrier recovery, that is recovery accomplished within 12-24 h [111]. This happened due to lateral migration of intact cells to the wounded site. In this regard, application of RF technology demonstrated almost complete and natural recovery of the skin in $24 \mathrm{~h}$ [86].

However, ablative fractional laser along with other laser techniques may possess harmful effects on the laser-treated skin. For instance, topically applied drugs may permeate across the microchannels created in the skin to reach systemic circulation that may end up with systemic toxicity. Lidocaine and its metabolites were detected in the serum of pig when pig skin model was used [142]. In addition, laser breaks natural skin barrier, allowing pathogen to enter from the skin surface or from non-sterile transdermal preparations directly into interior of the skin. Furthermore, chances of immunological sensitization from some drugs and additives in the formulation possess another safety concern [143]. Therefore, it is of utmost importance to exercise thermal ablation techniques to deliver drugs in well-controlled settings, employing type, duration of application of techniques, and amount of drug suitable for administration.

\section{Conclusion and future perspectives}

Presently, the concept in which formulations used to delivery drug across the skin is well-understood and accepted by the general public. In addition, the simplified regulation made it possible to purchase patches like nicotine from pharmacy or supermarket as over-the-counter drugs. The TDD market is growing in a good pace, which has the potential to occupy second place to oral route. According to a report, the TDD market represents multi-billion dollar market annually [144]. The TDD is one such drug administration route which can give return on investment. For instance, TDDS of fentanyl had an annual sales exceeding 1 billion US dollar in the last 5 years.

Despite these, the barrier nature of the SC limits many drugs to be considered for TDD. However, the advancements in enhancing the skin permeability by different technologies made the skin a promising route of drug administration. Particularly, third-generation physical enhancement techniques constitute thermal ablation, laser ablation, and RFassisted delivery which are capable of delivering 
Table 3 Different thermal ablation techniques with devices used to deliver various classes of drugs and their obtained results

\begin{tabular}{|c|c|c|c|c|}
\hline $\begin{array}{l}\text { Ablation } \\
\text { method }\end{array}$ & Formulations/device & $\begin{array}{l}\text { Drugs with their physicochemical } \\
\text { properties }\end{array}$ & Results & References \\
\hline \multirow[t]{2}{*}{$\begin{array}{r}\text { Chemical } \\
\text { heating }\end{array}$} & $\begin{array}{l}\text { Carboxymethyl } \\
\text { cellulose-based matrix }\end{array}$ & $\begin{array}{l}\text { Lidocaine }(\mathrm{MW}=234.3 \mathrm{Da}, \log P=2.4 \\
\quad \text { and plasma half-life }=1-2 \mathrm{~h})\end{array}$ & $\begin{array}{l}\text { A sharp temperature variation was } \\
\text { observed for the water as initiator } \\
\text { compared with slow and controlled } \\
\text { oxidation induced by oxygen. }\end{array}$ & {$[60]$} \\
\hline & $\begin{array}{l}\text { Patch/CHADD }{ }^{\mathrm{TM}} \text { heating } \\
\text { POD }\end{array}$ & $\begin{array}{l}\text { Lidocaine and prilocaine } \\
(\mathrm{MW}=220.3 \mathrm{Da}, \log P=2.1 \text { and } \\
\text { plasma half-life }=1-2 \mathrm{~h})\end{array}$ & $\begin{array}{l}\text { Improved the drug permeation } \\
\text { significantly. }\end{array}$ & {$[63]$} \\
\hline \multirow[t]{6}{*}{ Thermoporation } & --- & Calcein & $\begin{array}{l}\text { Optimum conditions led to } 760 \text {-fold in- } \\
\text { crease in calcein transdermal delivery. }\end{array}$ & {$[20]$} \\
\hline & $\begin{array}{l}\text { Integrated patch composed of } \\
\text { polydimethylsiloxane patch } \\
\text { and micro-heaters. }\end{array}$ & Glucose & $\begin{array}{l}\text { Formed micropores were capable of } \\
\text { diffusing biomolecules such as glucose } \\
\text { across skin. }\end{array}$ & {$[68]$} \\
\hline & PassPort ${ }^{\mathrm{TM}}$ system & $\begin{array}{l}\text { Interferon alpha-2b (INFa2b) (half-life }= \\
5-6 \mathrm{~h} \text { and } \mathrm{MW}=19.271 \mathrm{kDa})\end{array}$ & $\begin{array}{l}\text { Drug delivery was improved with the } \\
\text { simultaneous use of microporation and } \\
\text { cathodal iontophoresis. }\end{array}$ & {$[75]$} \\
\hline & Vaccine/PassPort ${ }^{\mathrm{TM}}$ system & Recombinant H5 haemagglutinin & Enhanced immunogenicity in the mice. & {$[65]$} \\
\hline & $\begin{array}{l}\text { Drug in PBS/fabricated ther- } \\
\text { mal ablation device }\end{array}$ & $\begin{array}{l}\text { Sulforhodamine }(\mathrm{MW}=558 \mathrm{Da}) \text { and BSA } \\
\quad \mathrm{MW}=66,000 \mathrm{Da})\end{array}$ & $\begin{array}{l}\text { Improved skin permeability of } 104 \text {-fold } \\
\text { and } 103 \text {-fold, respectively }\end{array}$ & {$[21]$} \\
\hline & Tixel & $\begin{array}{l}\text { Verapamil } \mathrm{HCl}(\mathrm{MW}=491.1 \mathrm{Da} \text {, plasma } \\
\text { half-life }=2-7 \mathrm{~h}, \log P=3.8, \text { and } \\
\text { pKa }=4.0) \text {, diclofenac sodium } \\
(\mathrm{MW}=318.1 \mathrm{Da}, \text { plasma } \\
\text { half-life }=1-2 \mathrm{~h}, \log P=4.5, \text { and } \\
\text { pKa }=4.0) \text {, and magnesium ascorbyl } \\
\text { phosphate }(\mathrm{MW}=176.1 \mathrm{Da})\end{array}$ & $\begin{array}{l}\text { Significant enhancement of drug } \\
\text { permeation. }\end{array}$ & {$[76]$} \\
\hline \multirow[t]{4}{*}{ Radiofrequency } & $\begin{array}{l}\text { Granisetron solution in PBS } \\
\text { pH } 7.4 \text { and diclofenac } \\
\text { sodium in ethyl alcohol: } \\
\text { PBS pH } 7.4(1: 9) / V^{2} \text { iaDor } \\
\end{array}$ & $\begin{array}{l}\text { Diclofenac sodium and granisetron } \mathrm{HCl} \\
(\mathrm{MW}=348.9 \mathrm{Da} \text {, half-life }=3-4 \mathrm{~h} \text { and } \\
\mathrm{pKa}=9.4)\end{array}$ & $\begin{array}{l}\text { Compared with passive diffusion, there } \\
\text { were } 8 \text {-fold and } 30 \text {-fold increase in } \\
\text { diclofenac sodium and granisetron } \mathrm{HCl} \\
\text { plasma concentration after } 6 \mathrm{~h} \text { and } 24 \mathrm{~h} \\
\text { of study, respectively. }\end{array}$ & {$[85]$} \\
\hline & ViaDor $^{\mathrm{TM}}$ & $\begin{array}{l}\text { Human growth hormone }(\mathrm{hGH}) \\
\qquad(\mathrm{MW}=22 \mathrm{kDa})\end{array}$ & $\begin{array}{l}75 \% \text { increase in bioavailability of hGH in } \\
\text { rat model, whereas 33\% increase of } \\
\text { bioavailability in guinea pig, compared } \\
\text { with subcutaneous injections. }\end{array}$ & {$[83]$} \\
\hline & ViaDor ${ }^{\mathrm{TM}}$ & $\begin{array}{l}\text { Gene delivery and expression of a } \\
\beta \text {-galactosidase reporter plasmid DNA }\end{array}$ & $\begin{array}{l}\text { The intensity and extent of gene expression } \\
\text { was found to be better when DNA } \\
\text { formulation was applied prior to the } \\
\text { application of ViaDor }\end{array}$ & {$[84]$} \\
\hline & ViaDor ${ }^{\mathrm{TM}}$ & $\begin{array}{l}\text { Testosterone }(\mathrm{MW}=288.4 \mathrm{Da}, \log P=3.3 \\
\text { and practically insoluble in water) }\end{array}$ & $\begin{array}{l}\text { The delivery of testosterone-cyclodextrin } \\
\text { complex was significantly increased and } \\
\text { the delivery was also extended up to } \\
24 \text { h post device application }\end{array}$ & {$[86]$} \\
\hline \multirow[t]{5}{*}{ Laser } & Er:YAG laser & $\begin{array}{l}\text { Morphine }(\mathrm{MW}=303.4 \mathrm{Da}, \log P \\
(\text { octanol } / \mathrm{pH} 7.4)=-0.1, \mathrm{pKa}=8.0, \text { and } \\
\text { plasma half-life, about } 2 \text { to } 3 \mathrm{~h}) \\
\text { nalbuphine }(\mathrm{MW}=357.4, \text { plasma } \\
\text { half-life, about } 5 \mathrm{~h}, \log P=0.2), \text { and } \\
\text { buprenorphine }(\mathrm{MW}=467.6 \mathrm{Da}, \log \\
P=4.98, \text { Plasma half-life }=1.2 \text { to } 7.2 \mathrm{~h}, \\
\text { and } \mathrm{pKa}=8.5,10.0)\end{array}$ & $\begin{array}{l}\text { There was } 10 \text { to } 35 \text {-fold enhancement of all } \\
\text { the drugs, which depends on the fluence } \\
\text { (used at } 1.7 \text { and } 2.6 \mathrm{~J} / \mathrm{cm}^{2} \text { ), } \\
\text { lipophilicity, and } \mathrm{MW} \text { of the individual } \\
\text { drug. }\end{array}$ & {$[100]$} \\
\hline & Er:YAG laser & $\begin{array}{l}\text { Nalbuphine and indomethacin } \\
\quad(\mathrm{MW}=357 \mathrm{Da}, \log P=4.2, \text { plasma } \\
\text { half-life }=3 \text { to } 15 \mathrm{~h} \text {, and } \mathrm{pKa}=4.5 \text { ) }\end{array}$ & $\begin{array}{l}\text { Flux of nalbuphine and indomethacin were } \\
\text { increased by } 73 \text {-fold and } 7.5 \text {-fold, re- } \\
\text { spectively. }\end{array}$ & {$[101]$} \\
\hline & Ruby, Er:YAG and $\mathrm{CO}_{2}$ & $\begin{array}{l}\text { 5-fluorouracil }(\mathrm{MW}=130.1 \mathrm{Da} \text {, sparingly } \\
\text { soluble in water, and } \mathrm{pKa}=8.0,13.0)\end{array}$ & $\begin{array}{l}\text { Ruby laser moderately enhanced skin } \\
\text { permeation. However, Er:YAG and } \\
\mathrm{CO}_{2} \text { enhanced skin permeation by 53- } \\
\text { tol33-fold and 36- to } 41 \text {-fold higher } \\
\text { than that of intact skin, respectively. }\end{array}$ & {$[96]$} \\
\hline & Nd:YAG laser & 5-Fluorouracil & $\begin{array}{l}\text { Enhanced the skin permeation more than } \\
\text { 182-fold compared with intact skin. }\end{array}$ & {$[102]$} \\
\hline & Nd:YAG laser & Glycerol & & {$[103]$} \\
\hline
\end{tabular}


Table 3 (continued)

\begin{tabular}{llll}
\hline $\begin{array}{l}\text { Ablation } \\
\text { method }\end{array}$ & Formulations/device & $\begin{array}{l}\text { Drugs with their physicochemical } \\
\text { properties }\end{array}$ & Results \\
\hline
\end{tabular}

Er:YAG laser

Er:YAG laser

Er:YAG and $\mathrm{CO}_{2}$ lasers

Er:YAG and $\mathrm{CO}_{2}$ lasers

Hollow gold nanocells/Er:YAG laser

$0.4 \%$ from an aqueous vehicle/Er:YAG laser

Er:YAG and Nd:YAG

Er:YAG and $\mathrm{CO}_{2}$ lasers

$\mathrm{CO}_{2}$ laser

P.L.E.A.S.E.® device

P.L.E.A.S.E.® device

P.L.E.A.S.E.® device

P.L.E.A.S.E.® device
Antisense oligonucleotides (ASOs)

Peptides (MW ranged from 5000 to $8000 \mathrm{Da})$ and related vaccine $(\mathrm{MW}=14,307 \mathrm{Da})$

Magnesium ascorbyl phosphate

Ascorbic acid 2-glucoside (AA2G) and 3-O-ethyl ascorbic acid (EAC)

respectively, compared with intact skin Doxorubicin $(\mathrm{MW}=543.5 \mathrm{Da}, \log P=1.3$ Combination of laser and intratumoral and hydrophilic nature)

Imiquimod $(\mathrm{MW}=240.3$ and $\log P=2.7$ )

5-aminolevulinic acid (MW = 167.6 Da and hydrophilic nature with $\mathrm{SC} /$ water partition coefficient $=0.1$ )

Small interfering RNA (siRNA)

Fluorescein isothiocyanat-labelled dextran $(\mathrm{MW}=4,10,20$ and $40 \mathrm{kDa})$

Lidocaine

Prednisolone $(\mathrm{MW}=360.4 \mathrm{Da}$, and $\log$ $P=1.6)$

Diclofenac

3-fluoroamphetamine $\mathrm{HCl}$ $(\mathrm{MW}=189.66 \mathrm{Da}$ and $\mathrm{pka}=9.97)$
Glycerol permeation enhancing capacity possessed by both the modes: long-pulsed $\left(15 \mathrm{~J} / \mathrm{cm}^{2}\right)$ and Q-switched $\left(0.5 \mathrm{~J} / \mathrm{cm}^{2}\right)$

Antisense oligonucleotides permeation and [104] DNA expression were found to be enhanced by 3 - to 35 -fold and 160 -fold, respectively, for ablated skin than that of intact skin.

3- to140-fold increase in peptide permeation across the partly ablated skin of mice compared with untreated skin.

Er:YAG laser and $\mathrm{CO}_{2}$ laser enhanced magnesium ascorbyl phosphate permeation by 86.04 - to 260.86 -fold and 8.19-fold, respectively.

Er:YAG laser enhanced the permeation by [107] 35- to 78-fold and 105- to189-fold for AA2G and EAC, respectively. Whereas $\mathrm{CO}_{2}$ increased the flux by 82 -fold and 181-fold for AA2G and EAC, injection showed maximum tumour necrosis compared with treatment without laser

$0.4 \%$ from an aqueous vehicle in combination with laser treatment produces approximately same flux as commercial cream with $5 \%$ of imiquimod dose without laser treatment

Drug permeation was found to be increased in laser ablated treated skin and the highest flux enhancement was found to be 200.3-fold

There were 11-fold and 12-fold increase in [110] fluxes of siRNA for Er:YAG and $\mathrm{CO}_{2}$ laser, respectively, compared with laser-untreated skin.

Improve the skin permeation enhancement of compounds of diverse MW.

P.L.E.A.S.E. ( ${ }^{B}$ has the ability to create well-defined pores of size $(150-200 \mu \mathrm{m})$ in the skin, and able to enhance both the rate and extent of lidocaine permeation.

There was a 4-fold increase in pore numbers (450 to 1800$)$ which demonstrated more than 3-fold increase in drug permeation and deposition.

Increasing number of pores from 150 to 900 leads to increase in diclofenac delivery from 3.7 -fold to 13 -fold enhancement compared with laser-untreated skin. Likewise, there was more than 3-fold increase in permeation of drug with 6-fold increase in fluency.

Compared with passive method, there were [119] 508-fold and 548-fold increase in drug permeation for laser-treated microporated skin and anodal 
Table 3 (continued)

\begin{tabular}{|c|c|c|c|c|}
\hline $\begin{array}{l}\text { Ablation } \\
\text { method }\end{array}$ & Formulations/device & $\begin{array}{l}\text { Drugs with their physicochemical } \\
\text { properties }\end{array}$ & Results & References \\
\hline & & & $\begin{array}{l}\text { iontophoresis, respectively. In addition, } \\
\text { ablative laser technique showed mini- } \\
\text { mum lag time. }\end{array}$ & \\
\hline & $\begin{array}{l}\text { Microparticles/P.L.E.A.S.E. }{ }^{\text {device }} \\
\text { (n) }\end{array}$ & $\begin{array}{l}\text { Pentoxifylline (relatively hydrophilic with } \\
\qquad \log P=-0.149 \pm 0.759 \text { ) }\end{array}$ & $\begin{array}{l}\text { Drug deposited in the micropores produces } \\
\text { an intraepidermal depot that ensure } \\
\text { sustained drug release without repeated } \\
\text { microporation as well as after the closer } \\
\text { of micropores }\end{array}$ & {$[120]$} \\
\hline & P.L.E.A.S.E.® device & Hepatitis B surface antigen (HBsAg) & $\begin{array}{l}\text { Optimized HBsAg induced similar } \\
\text { antibody titers compared with } \\
\text { intramuscular injection of HBsAg }\end{array}$ & [122] \\
\hline
\end{tabular}

Table 4 List of patent granted by various authorities on different thermal techniques to improve skin permeation

\begin{tabular}{|c|c|c|c|c|c|}
\hline $\begin{array}{l}\text { S. } \\
\text { no }\end{array}$ & Patent number & Inventor & Current assignee & Technique & Reference \\
\hline 1 & US6708060B1 & $\begin{array}{c}\text { Zohar Avarhami, } \\
\text { Ze'ev Sohn }\end{array}$ & Syneron Medical Ltd. & RF-assisted & [124] \\
\hline 2 & US7395111B2 & $\begin{array}{l}\text { Galit Levin, Meir } \\
\text { Stern, Dorit Daniel }\end{array}$ & Syneron Medical Ltd. & RF-assisted & {$[125]$} \\
\hline 3 & US 6148232 & Zohar Avrahami & $\begin{array}{l}\text { Syneron Medical Ltd., } \\
\text { TransPharma Ltd }\end{array}$ & RF-assisted & {$[126]$} \\
\hline 4 & US7452358B2 & $\begin{array}{l}\text { Roger A. Stern, } \\
\text { Mitchell Levinson, } \\
\text { Bryan Weber }\end{array}$ & Solta Medical Inc. & RF-assisted & {$[127]$} \\
\hline 5 & US7481809B2 & $\begin{array}{l}\text { Roger A. Stern, } \\
\text { Mitchell Levinson, } \\
\text { Bryan Weber }\end{array}$ & Solta Medical Inc. & RF-assisted & [128] \\
\hline 6 & US4775361A & $\begin{array}{l}\text { Stephen L. Jacques et. } \\
\text { al }\end{array}$ & $\begin{array}{l}\text { General hospital corp of } \\
\text { MA, General } \\
\text { Hospital Corp. }\end{array}$ & Laser-assisted & [129] \\
\hline 7 & WO1997007734A1 & $\begin{array}{l}\text { Jonathan A. Eppstein } \\
\text { et. al }\end{array}$ & & & {$[130]$} \\
\hline 8 & WO2001050963A1 & $\begin{array}{l}\text { Kevin S.Marchitto, } \\
\text { Stephen T. Flock }\end{array}$ & & Laser-assisted & {$[131]$} \\
\hline 9 & US5643252A & Milton Waner et. al & $\begin{array}{l}\text { Transmedica } \\
\text { International Inc. }\end{array}$ & Laser-assisted & {$[132]$} \\
\hline 10 & US20050247321A1 & $\begin{array}{l}\text { Milton Waner, } \\
\text { Charles Vestal, } \\
\text { Stephen Flock }\end{array}$ & & Laser-assisted & [133] \\
\hline 11 & US20100292680A1 & $\begin{array}{l}\text { Thomas Bragagna, } \\
\text { Arne Heinrich, } \\
\text { Simon Gross }\end{array}$ & PantechBiosolutios AG & Laser-assisted & {$[134]$} \\
\hline 12 & WO2006111201A1 & $\begin{array}{l}\text { Thomas Bragagna et. } \\
\text { al }\end{array}$ & & Laser-assisted & {$[135]$} \\
\hline 13 & ES2334705T3 & Christof Bohler et. al & $\begin{array}{l}\text { PantechBiosolutions } \\
\text { AG }\end{array}$ & Laser-assisted & [136] \\
\hline 14 & EP1874213B1 & Christof Bohler et. al & $\begin{array}{l}\text { PantechBiosolutions } \\
\text { AG }\end{array}$ & Laser-assisted & {$[137]$} \\
\hline 15 & US8116860B2 & $\begin{array}{l}\text { Bernadette Messier et. } \\
\text { al }\end{array}$ & Nitto Denko Corp. & $\begin{array}{l}\text { Thermal } \\
\text { ablation }\end{array}$ & {$[138]$} \\
\hline 16 & US6711435B2 & Zohar Avarhami & $\begin{array}{l}\text { Syneron Medical Ltd., } \\
\text { Transpharma }\end{array}$ & Thermal & [139] \\
\hline 17 & EP1450876B1 & Zeev Sohn & Syneron Medical Ltd. & Thermal & {$[140]$} \\
\hline 18 & WO2006004595A2 & Mark Prausnitz et. al & & Thermal & {$[141]$} \\
\hline
\end{tabular}


macromolecules, vaccines, and peptides by creating microchannels in the $\mathrm{SC}$ while protecting underlying tissues. These ablation techniques eliminate pain and inconvenience of injections and limitations caused by other traditional routes of drug delivery.

More precisely, thermal ablation technique is the combination of drug delivery system and device. The latter is to reduce the barrier property of the skin. The combination expected to face more regulatory challenges, but it can open up broader clinical scope. In other words, we can describe the above combination as electronic-based drug delivery system. As per report, it has a small share of the global advanced drug delivery technology market and expected to reach approximately 227 billion US dollar by 2020 [145]. In the present scenario, these systems, i.e. first to third generation of drug delivery systems, has huge market potential due to their advantages such as accurate and specific drug delivery, reduce side effects, and improved medication compliance.

The most recent advancement in the personalized therapy necessitates a paradigm shift in TDD. This is because personalized therapy requires treatment optimization depending on pathophysiological conditions of each individual [146] in order to maximize therapeutic efficacy. This is only possible with the transdermal systems having potential to induce feedback-regulated control release of incorporated drugs. Such needs can only be catered with sensor- and actuatorbased wearable devices $[147,148]$. Therefore, deviceassisted TDDS are containing two parts: TDDS and soft bioelectronics. They control the drug release with simultaneous monitoring of altered physiological states of the individual by the drug. These types of wearable devices are envisaged as fourth-generation transdermal delivery systems. One example is thrombin-responsive microneedle array which is capable of preventing unwanted blood coagulation [149]. In increased glucose responsive delivery of insulin, microneedle array having embedded dual-responsive (hypoxia and $\mathrm{H}_{2} \mathrm{O}_{2}$ ) vehicles is another example [150]. Patient-based TDD is still in the starting stage, which requires much attention in terms of research and development for the convenient management of disease in future.

\section{Compliance with ethical standards}

Conflict of interest The authors declare that they have no of conflict of interest.

\section{References}

1. Menon GK. New insights into skin structure: scratching the surface. Adv Drug Deliv Rev. 2002;54:S3-S17.

2. Waller JM, Maibach HI. Age and skin structure and function, a quantitative approach (I): blood flow, $\mathrm{pH}$, thickness, and ultrasound echogenicity. Skin Res Technol. 2005;11:221-35.
3. Parhi R, Suresh P, Mondal S, Kumar PM. Novel penetration enhancers for skin applications: a review. Curr Drug Deliv. 2012;9: 219-30.

4. Pegoraro C, MacNeil S, Battaglia G. Transdermal drug delivery: from micro to nano. Nanoscale. 2012;4:1881-94.

5. Shahzad Y, Afreen U, Shah SNH, Hussain T. Applying response surface methodology to optimize nimesulide permeation from topical formulation. Pharm Dev Technol. 2013;18:1391-8.

6. Singh S, Parhi R, Garg A. Formulation of topical bioadhesive gel of aceclofenac using 3-level factorial design. Iran J Pharm Res. 2011;10:435-45.

7. Anjos JLV, Neto DS, Alonso A. Effects of 1,8-cineole on the dynamics of lipids and proteins of stratum corneum. Int $\mathrm{J}$ Pharm. 2007;345:81-7.

8. Mills PC, Cross SE. Transdermal drug delivery: basic principles for the veterinarian. Vet J. 2006;172:218-33.

9. Jayaprakash R, Hameed J. Anupriya. An overview of transdermal delivery system. Asian J Pharm Clin Res. 2017;10:36-40.

10. Jawale NR, Bhangale CD, Chaudhari MA, Deshmukh TA. Physical approach to transdermal drug delivery: a review. J Drug Deliv Ther. 2017;7:28-35.

11. Miller MA, Pisani E. The cost of unsafe injections. Bull World Health Organ. 1999;77:808-11.

12. Lopez RFV, Seto JE, Blankschtein D, Langer R. Enhancing the transdermal delivery of rigid nanoparticles using the simultaneous application of ultrasound and sodium lauryl sulphate. Biomater. 2011;32:933-41.

13. Lee H, Song C, Baik S, Kim D, Hyeon T, Kim D-H. Deviceassisted transdermal drug delivery. Adv Drug Deliv Rev. 2018;127:35-45.

14. Wiedersberg S, Guy RH. Transdermal drug delivery: 30+ years of war and still fighting! J Control Release. 2014;190:150-6.

15. Alkilani AZ, McCrudden MTC, Donnelly RF. Transdermal drug delivery: innovative pharmaceutical developments based on disruption of the barrier properties of the stratum corneum. Pharm J. 2015;7:438-70.

16. Choi WI, Lee JH, Kim J-Y, Kim J-C, Kim YH, Tae G. Efficient skin permeation of soluble proteins via flexible and functional nano-carrier. J Control Release. 2012;157:272-8.

17. Parhi R, Suresh P, Patnaik P. Physical means of stratum corneum barrier manipulation to enhance transdermal drug delivery. Curr Drug Deli. 2015;12:122-38.

18. Parhi R, Swain S. Transdermal evaporation drug delivery system: concept to commercial products. Adv Pharm Bull. 2018;8:53550 .

19. Arora A, Prausnitz M, Mitragotri S. Micro-scale devices for transdermal drug delivery. Int J Pharm. 2009;364:227-36.

20. Park J-H, Lee J-W, Kim Y-C, Prausnitz MR. The effect of heat on skin permeability. Int J Pharm. 2008;359:94-103.

21. Lee JW, Gadiraju P, Park J, Allen MG, Prausnitz MR. Microsecond thermal ablation of skin for transdermal drug delivery. J Control Release. 2011;154:58-68.

22. Senyigit T, Ozer O. Corticosteroids for skin delivery: challenges and new formulation opportunities: IntechOpen; 2012. https://doi. org/10.5772/53909.

23. Latheeshjlal L, Phanitejaswini P, Soujanya Y, Swapna U, Sarika V, Moulika G. Transdermal drug delivery systems: an overview. Int J PharmTechnol Res. 2011;3:2140-8.

24. Bala P, Jathar S, Kale S, Pal K. Transdermal drug delivery system (TDDS)-a multifaceted approach for drug delivery. J Pharm Res. 2014;8:1805-35.

25. Kumbhar VB, Malpure PS, More YM. A Review on transdermal drug delivery system 2018;7:1258-69.

26. Aljuffali IA, Lin C-F, Fang J-Y. Skin ablation by physical techniques for enhancing dermal/transdermal drug delivery. J Drug Deliv Sci Technol. 2014;24:277-87. 
27. Menon G, Ghadially R. Morphology of lipid alterations in the epidermis: a review. Micros Res Tech. 1997;37:180-92.

28. Potts RO, Guy RH. Predicting skin permeability. Pharm Res. 1992;9:663-9.

29. Jhawat VC, Saini V, Kamboj S, Maggon N. Transdermal drug delivery systems: approaches and advancements in drug absorption through skin. Int J Pharm Sci Rev Res. 2013;20:47-56.

30. Rastogi V, Yadav P. Transdermal drug delivery system: an overview. Asian J Pharm. 2012;6:161-70.

31. Lademann J, Richter H, Schanzer S, Knorr F, Meinke M, Sterry $\mathrm{W}$, et al. Penetration and storage of particles in human skin: perspectives and safety aspects. Eur J Pharm Biopharm. 2011;77: 465-8.

32. Lane ME. Skin penetration enhancers. Int J Pharm. 2013;447:1221.

33. Prausnitz MR, Langer R. Transdermal drug delivery. Nat Biotechnol. 2008;26:1261-8.

34. Sifton DW. Physicians' desk reference, Medical Economics/ Thomson Healthcare, 2002.

35. Alexander DS, Giri TK, Ajazuddin SS, Saraf S, Tripathi DK. Approaches for breaking the barriers of drug permeation through transdermal drug delivery. J Control Release. 2012;164:26-40.

36. Prow TW, Grice JE, Lin LL, Faye R, Butler M, Becker W, et al. Nanoparticles and microparticles for skin drug delivery. Adv Drug Deliv Rev. 2011;63:470-91.

37. Ge S, Lin Y, Lu H, Li Q, He J, Chen B, et al. Percutaneous delivery of econazole using microemulsion as vehicle: formulation, evaluation and vesicleskin interaction. Int J Pharm. 2014;465:120-31.

38. Lai F, Pireddu R, Corrias F, Fadda AM, Valenti D, Pini E, et al. Nanosuspension improves tretinoin photostability and delivery to the skin. Int J Pharm. 2013;458:104-9.

39. Elnaggar YS, El-Refaie WM, El-Massik MA, Abdallah OY. Lecithin-based nanostructured gels for skin delivery: an update on state of art and recent applications. J Control Release. 2014;180:10-24.

40. Lee H, Lee Y, Song C, Cho HR, Ghaffari R, Choi TK, et al. An endoscope with integrated transparent bioelectronics and theranostic nanoparticles for colon cancer treatment. Nat Commun. 2015;6:10059.

41. Kim H, Lee H, Seong KY, Lee E, Yang SY, Yoon J. Visible lighttriggered on-demand drug release from hybrid hydrogels and its application in transdermal patches. Adv Healthc Mater. 2015;4: 2071-7.

42. Di J, Yao S, Ye Y, Cui Z, Yu J, Ghosh TK, et al. Stretch-triggered drug delivery from wearable elastomer films containing therapeutic depots. ACS Nano. 2015;9:9407-15.

43. Cazares-Delgadillo J, Ganem-Rondero A, Merino V, Kalia YN. Controlled transdermal iontophoresis for poly-pharmacotherapy: simultaneous delivery of granisetron, metoclopramide and dexamethasone sodium phosphate in vitro and in vivo. Eur J Pharm Sci. 2016;85:31-8.

44. Pereira TA, Ramos DN, Lopez RF. Hydrogel increases localized transport regions and skin permeability during low frequency ultrasound treatment. Sci Rep. 2017;7:44236.

45. Batheja P, Sheihet L, Kohn J, Singer AJ, Michniak-Kohn B. Topical drug delivery by a polymeric nanosphere gel: formulation optimization and in vitro and in vivo skin distribution studies. J Control Release. 2011;149:159-67.

46. Chen H, Chang X, Weng T, Zhao X, Gao Z, Yang Y, et al. A study of microemulsion systems for transdermal delivery of triptolide. J Control Release. 2004;98:427-36.

47. Honeywell-Nguyen PL, Bouwstra JA. Vesicles as a tool for transdermal and dermal delivery. Drug Discov Today Technol. 2005;2: $67-74$.
48. Gratieri T, Alberti I, Lapteva M, Kalia YN. Next generation intraand transdermal therapeutic systems: using non- and minimallyinvasive technologies to increase drug delivery into and across the skin. Eur J Pharm Sci. 2013;50:609-22.

49. Chen MC, Lin ZW, Ling MH. Near-infrared light-activatable microneedle system for treating superficial tumors by combination of chemotherapy and photothermal therapy. ACS Nano. 2016;10: 93-101.

50. Hirobe S, Azukizawa H, Hanafusa T, Matsuo K, Quan YS, Kamiyama F, et al. Clinical study and stability assessment of a novel transcutaneous influenza vaccination using a dissolving microneedle patch. Biomater. 2015;57:50-8.

51. Wang C, Ye Y, Hochu GM, Sadeghifar H, Gu Z. Enhanced cancer immunotherapy by microneedle patch-assisted delivery of antiPD1 antibody. Nano Lett. 2016;16:2334-40.

52. Edens C, Dybdahl-Sissoko NC, Weldon WC, Oberste MS, Prausnitz MR. Inactivated polio vaccination using a microneedle patch is immunogenic in the rhesus macaque. Vaccine. 2015;33: 4683-90.

53. Brown MB, Martin GP, Jones SA, Akomeah FK. Dermal and transdermal drug delivery systems: current and future prospects. Drug Deliv. 2006;13:175-87.

54. Williams AC, Barry BW. Terpenes and the lipid-proteinpartitioning theory of skin penetration enhancement. Pharm Res. 1991;8:17-24

55. Angamuthu M, Ainampudi S. Role of physical, chemical percutaneous penetration enhancement methods: a concise review. J Nanomed Biother Discov. 2017;7.

56. Hussain A, Wahab GMKA, ur Rahman MAS, Altaf H, Akhtar N, Qayyum MI. Potential enhancers for transdermal drug delivery: a review. Int J Basic Med Sci Pharm. 2014;4:19-22.

57. Shahzad Y, Louw R, Gerber M, du Plessis J. Breaching the skin barrier through temperature modulations. J Control Release. 2015;202:1-13.

58. Schaepelynck P, Darmon P, Molines L, Jannot-Lamotte MF, Treglia C, Raccah D. Advances in pump technology: insulin patch pumps, combined pumps and glucose sensors, and implanted pumps. Diabetes Metab. 2011;37(Supplement 4):S85-93.

59. Verspohl EJ. Novel pharmacological approaches to the treatment of type 2 diabetes. Pharmacol Rev. 2012;64:188-237.

60. Wood DG, Brown MB, Jones SA. Controlling barrier penetration via exothermic iron oxidation. Int J Pharm. 2011;404:42-8.

61. Hammonds WD, Hord AH. Additional comments regarding an anaesthesiology based postoperative pain service. Anesthesiology. 1988;69:139-40.

62. Z. Pharma, Synera ${ }^{\circledR}$ : topical analgesic patch, 2008. http://www. synera.com/health-care-professionals/efficacy/. Accessed 03 Dec 2019.

63. Sawyer J, Febbraro S, Masud S, Ashburn MA, Campbell JC. Heated lidocaine/tetracaine patch $\left(\right.$ Synera $^{\mathrm{TM}}$, Rapydan $\left.^{\mathrm{TM}}\right)$ compared with lidocaine/prilocaine cream (EMLA®) for topical anaesthesia before vascular access. Br J Anaesth. 2009;102:210-5.

64. Herwadkar A, Banga AK. Peptide and protein transdermal drug delivery. Drug Discov Today Technol. 2012;9.

65. Lakshmanan S, Gupta GK, Avci P, Chandran R, Sadasivam M, Jorge AES, et al. Physical energy for drug delivery; poration, concentration and activation. Adv Drug Deliv Rev. 2014;71:9814.

66. Garg S, Hoelscher M, Belser JA, Wang C, Jayashankar L, Guo Z, et al. Needle-free skin patch delivery of a vaccine for a potentially pandemic influenza virus provides protection against lethal challenge in mice. Clin Vaccine Immunol. 2007;14:926-8.

67. Lepock JR, Frey HE, Bayne H, Markus J. Relationship of hyperthermia-induced hemolysis of human erythrocytes to the thermal denaturation of membrane proteins. Biochim Biophys Acta Biomembr. 1989;980:191-201. 
68. Paranjape M, Garra J, Brida S, Schneider T, White R, Currie J. A PDMS dermal patch for non-intrusive transdermal glucose sensing. Sensors Actuators A Phys. 2003;104:195-204.

69. Ahad A, Al-Saleh AA, Akhtar N, Al-Mohizea AM, Al-Jenoobi FI. Transdermal delivery of antidiabetic drugs: formulation and delivery strategies. Drug Discov Today. 2015;20:1217-27.

70. Patel YR, Damon S. PassPort ${ }^{\mathrm{TM}}$ apomorphine HCL patch: meeting unmet needs in management of Parkinson's disease Altea Therapeutics. https://pdfs.semanticscholar.org/3acc/ 0f6ae72ced8672215635659035e60b835350.pdf

71. Kalluri H, Banga AK. Transdermal delivery of proteins. AAPS PharmSciTech. 2011;12:431-41.

72. Banga AK. Microporation applications for enhancing drug delivery. Expert Opin Drug Deliv. 2009;6:343-54.

73. Kanguru L, Bezawada N, Hussein J, Bell J. The burden of diabetes mellitus during pregnancy in lowand middle-income countries: a systematic review. Glob Health Action. 2014;7:23987.

74. Ahad A, Aqil M, Kohli K, Sultana Y, Mujeeb M. Design, formulation and optimization of valsartan transdermal gel containing iso-eucalyptol as novel permeation enhancer: preclinical assessment of pharmacokinetic in Wistar albino rats. Expert Opin Drug Deliv. 2014;11:1149-62.

75. Badkar AV, Smith AM, Eppstein JA, Banga AK. Transdermal delivery of interferon alpha-2B using microporation and iontophoresis in hairless rats. Pharm Res. 2007;24:1389-95.

76. Sintova AC, Hofmann MA. A novel thermo-mechanical system enhanced transdermal delivery of hydrophilic active agents by fractional ablation. Int J Pharm. 2016;511:821-30.

77. Sintova AC, Krymberk I, Daniel D, Hannan T, Sohn Z, Levin G. Radiofrequency driven skin microchanneling as a new way for electrically assisted transdermal delivery of hydrophilic drugs. J Control Release. 2003;89:311-20.

78. Weiss RA. Noninvasive radio frequency for skin tightening and body contouring. Semin Cutan Med Surg. 2013;32:9-17.

79. Singh TRR, Garland MJ, Cassidy CM, Migalska K, Demir YK, Abdelghany S, et al. Microporation techniques for enhanced delivery of therapeutic agents. Recent Pat Drug Deliv Formul. 2010;4:1-17.

80. Levin G, Kornfeld J. RF-microchannel-based transdermal delivery. East Sussex: OndrugDelivery; 2007.

81. Mathur V, Satrawala Y, Rajput MS. Physical and chemical penetration enhancers in transdermal drug delivery system. Asian J Pharm. 2010;4:173-83.

82. Kornfeld J, Patel YR, Fox D. Crossing the barrier: RF transdermal drug delivery transpharma medical ltd. 2007.

83. Levin G, Gershonowitz A, Sacks H, Stern M, Sherman A, Rudaev $\mathrm{S}$, et al. Transdermal delivery of human growth hormone through RF microchannels. Pharm Res. 2005;22:550-5.

84. Birchall J, Coulman S, Anstey A, Gateley C, Sweetland H, Gershonowitz A, et al. Cutaneous gene expression of plasmid DNA in excised human skin following delivery via microchannels created by radio frequency ablation. Int J Pharm. 2006;312:15-23.

85. Dragicevic N, Maibach HI. Percutaneous penetration enhancers physical methods in penetration enhancement. 1st ed. Berlin Heidelberg: Springer-Verlag; 2017.

86. Kam Y, Sacks H, Kaplan KM, Stern M, Levin G. Radio frequency microchannels for transdermal delivery: characterization of skin recovery and delivery window. 2012;03:20-8.

87. Thomas G, Isaacs R. Basic principles of lasers, anaesthesia \& intensive care medicine. 2011;12:574-7.

88. del Rio-Sancho S, Castro-Lopez V, Alonso MJ. Enhancing cutaneous delivery with laser technology: almost there, but not yet. J Control Release. 2019;313:150-65.

89. Manstein D, Herron GS, Sink RK, Tanner H, Anderson RR. Fractional photothermolysis: a new concept for cutaneous remodeling using microscopic patterns of thermal injury. Lasers Surg Med. 2004;34:426-38.

90. Zgavec B, Stopajnik N. Clinical and histological evaluation of Er: YAG ablative fractional skin resurfacing. J Laser Health Acad. 2014;1:1-06.

91. Lin CH, Aljuffali IA, Fang JY. Lasers as an approach for promoting drug delivery via skin. Expert Opin Drug Deliv. 2014;11:599 614.

92. Omi T, Numano $\mathrm{K}$. The role of the $\mathrm{CO}_{2}$ laser and fractional $\mathrm{CO}(2)$ laser in dermatology. Laser Ther. 2014;23:49-60.

93. Kaplan GS. $\mathrm{CO}_{2}$ Laser Surgery. Berlin Heidelberg: Springer; 2012.

94. Menon GK, Kollias N, Doukas AG. Ultrastructural evidence of stratum corneum permeabilization induced by photomechanical waves. J Investig Dermatol. 2003;121:104-9.

95. Lee S, McAuliffe DJ, Flotte TJ, Kollias N, Doukas AG. Photomechanical transdermal delivery: the effect of laser confinement. Lasers Surg Med. 2001;28:344-7.

96. Mitragotri S. Devices for overcoming biological barriers: the use of physical forces to disrupt the barriers. Adv Drug Deliv Rev. 2013;65:100-3.

97. Lee W-R, Shen S-C, Wang K-H, Hu C-H, Fang J-Y. The effect of laser treatment on skin to enhance and control transdermal delivery of 5-fluorouracil. J Pharm Sci. 2002;91:1613-26.

98. Szunerits S, Boukherroub R. Heat: a highly efficient skin enhancer for transdermal drug delivery. Front Bioeng Biotechnol. 2018;6.

99. Bachhav YG, Summer S, Heinrich A, Bragagna T, Böhler C, Kalia YN. P.L.E.A.S.E. ${ }^{\circledR}$ A promising tool for intraepidermal drug delivery. Geneva: School of Pharmaceutical Sciences, University of Geneva \& University of Lausanne; 2008.

100. Lee WR, Shen SC, Fang CL, Liu CJ, Fang JY. Skin pretreatment with an Er:YAG laser promotes the transdermal delivery of three narcotic analgesics. Lasers Med Sci. 2007;22:271-8.

101. Lee WR, Shen SC, Lai HH, Hu CH, Fang JY. Transdermal drug delivery enhanced and controlled by erbium:YAG laser: a comparative study of lipophilic and hydrophilic drugs. J Control Release. 2001;75:155-66.

102. Gómez C, Costela Á, García-Moreno I, Llanes F, Teijón JM, Blanco D. Laser treatments on skin enhancing and controlling transdermal delivery of 5-fluorouracil. Lasers Surg Med. 2008;40:6-12.

103. Liu C, Zhang J, Yue Y, Luo Q, Zhu D. 1064 nm-Nd:YAG lasers with different output modes enhancing transdermal delivery: physical and physiological mechanisms. J Biomed Opt. 2013;18: 061228.

104. Lee WR, Shen SC, Liu CR, Fang CL, Hu CH, Fang JY. Erbium: YAG laser-mediated oligonucleotide and DNA delivery via the skin: an animal study. J Control Release. 2006;115:344-53.

105. Lee WR, Pan TL, Wang PW, Zhuo RZ, Huang CM, Fang JY. Erbium:YAG laser enhances transdermal peptide delivery and skin vaccination. J Control Release. 2008;128:200-8.

106. Lee WR, Shen SC, Wang KH, Hu CH, Fang JY. Lasers and microdermabrasion enhance and control topical delivery of vitamin C. J Invest Dermatol. 2003;121:1118-25.

107. Hsiao CY, Huang CH, Hu S, Ko YS, Sung HC, Huang SY. Skin pretreatment with lasers promotes the transdermal delivery of vitamin C derivatives. Lasers Med Sci. 2011;26:369-76.

108. Lee HJ, Liu Y, Zhao J, Zhou M, Bouchard RR, Mitcham T, Wallace M, Stafford RJ, Li C, Gupta S. Marites P. Melancon. In vitro and in vivo mapping of drug release after laser ablation thermal therapy with doxorubicin-loaded hollow gold nanoshells using fluorescence and photoacoustic imaging. J Control Release 2013;172:152-158.

109. Lee W-R, Shen S-C, Al-Suwayeh SA, Yang H-H, Yuan C-Y, Fang J-Y. Laser-assisted topical drug delivery by using a low- 
fluence fractional laser: imiquimod and macromolecules. J Control Release. 2011;153:240-8.

110. Gomez C, Costela A, Garcia-Moreno I, Llanes F, Teijon JM, Blanco MD. Skin laser treatments enhancing transdermal delivery of ALA. J Pharm Sci. 2011;100:223-31.

111. Lee W-R, Shen S-C, Chen W-Y, Aljuffali IA, Suen S-Y, Fang JY. Noninvasive delivery of siRNA and plasmid DNA into skin by fractional ablation: Erbium:YAG laser versus $\mathrm{CO}_{2}$ laser. Eur J Pharm Biopharm. 2014;86:315-23.

112. Lee W-R, Shen S-C, Al-Suwayeh SA, Yang H-H, Li Y-C, Fang JY. Skin permeation of small-molecule drugs, macromolecules, and nanoparticles mediated by a fractional carbon dioxide laser: the role of hair follicles. Pharm Res. 2013;30:792-802.

113. https://www.medgadget.com/2008/02/pleasepainless_laser_ epidermal_system.html. Accessed 25 Nov 2019.

114. https://www.pantec-biosolutions.com/en/technology/p-l-e-a-s-etechnology. Accessed 25 Nov 2019.

115. https://www.medgadget.com/2008/12/please_to_improve effectiveness_of_drug_patches.html. Accessed 25 Nov 2019.

116. Bachhav YG, Summer S, Heinrich A, Bragagna T, Böhler C, Kalia YN. Effect of controlled laser microporation on drug transport kinetics into and across the skin. J Control Release. 2010;146: $31-6$.

117. Yu J, Bachhav YG, Summer S, Heinrich A, Bragagna T, Böhler $\mathrm{C}$, et al. Using controlled laser-microporation to increase transdermal delivery of prednisone. J Control Release. 2010;148:57-73.

118. Bachhav YG, Heinrich A, Kalia YN. Using laser microporation to improve transdermal delivery of diclofenac: increasing bioavailability and the range of therapeutic applications. Eur J Pharm Biopharm. 2011;78:408-14.

119. Puria A, Murnanea KS, Bloughb BE, Banga AK. Effects of chemical and physical enhancement techniques on transdermal delivery of 3-fluoroamphetamine hydrochloride. Int J Pharm. 2017;528: 452-62.

120. Gou S, del Rio-Sancho S, Singhal M, Laubach H-J, Kalia YN. Er: YAG fractional laser ablation for cutaneous co-delivery of pentoxifylline and D- $\alpha$-tocopherol succinate: a new approach for topical treatment of radiation-induced skin fibrosis. Eur J Pharm Sci. 2019;135:22-31.

121. Weiss R, Hessenberger M, SKitzmüller S, Bach D, Weinberger EE, Krautgartner WD, et al. Transcutaneous vaccination via laser microporation. J Control Release. 2012;162:391-9.

122. Scheiblhofer S, Strobl A, Hoepflinger V, Thalhamer T, Steiner M, Thalhamer J, et al. Skin vaccination via fractional infrared laser ablation-optimization of laser-parameters and adjuvantation. Vaccine. 2017;35:1802-9.

123. Van Der Walle C. Peptide and protein delivery. 1st ed. Cambridge: Academic Press; 2011.

124. Avrahami Z, Sohn Z. (2004) US patent no.6708060B1.

125. Levin G, Stern M, Daniel D. (2008) US patent no.7395111B2.
126. Avrahami Z. (2000) US Patent No. 6148232.

127. Stern RA, Levinson M, Weber B. 2008 US Patent No.7452358B2.

128. Stern RA, Weber B, Levinson M. 2009 US patent no.7481809B2.

129. Jacques SL, McAuliffe DJ, Blank IH, Parrish JA. 1988 US patent no.4775361A.

130. Eppstein JA, Hatch MR, Yang D. (1997) WO1997007734A1.

131. Marchitto KS, Flock ST. 2001 WO2001050963A1.

132. Waner M, Flock ST, Vestal CH. 1997 US patent no.5643252A.

133. Waner M, Vestal C, Flock S. 2005 US patent no.20050247321A1.

134. Bragagna T, Heinrich A, Gross S. 2010 US patent no. 20100292680A1.

135. Bragagna T, Braun R, Gfrerer D, Nussbaumer B. 2006 WO2006111201A1.

136. Bohler C, Bragagna T, Braun R, Gfrerer D, Nussbaumer B. 2006 ES2334705T3.

137. Bohler C, Bragagna T, Braun R, Gfrerer D, Nussbaumer B. 2008 EP1874213B1.

138. Messier B et al. 2012 US Patent No. 8116860B2.

139. Avarhami Z. 2004 US Patent No.6711435B2.

140. Sohn Z. 2016 EPPatent no.1450876B1.

141. Prausnitz M et al. 2006 WO2006004595A2.

142. Oni G, Brown SA, Kenkel JM. Can fractional lasers enhance transdermal absorption of topical lidocaine in an in vivo animal model? Lasers Surg Med. 2012;44:168-74.

143. Haedersdal M, Erlendsson AM, Paasch U, Anderson RR. Translational medicine in the field of ablative fractional laser (AFXL)-assisted drug delivery: a critical review from basics to current clinical status. J Am Acad Dermatol. 2016;74:981-1004.

144. Hadgraft J, Lane ME. Passive transdermal drug delivery systems. Recent considerations and advances. Am J Drug Deliv. 2006;4: 153-60.

145. Vadlapatla R, Wong EY, Gayakwad SG. Electronic drug delivery systems: an overview. J Drug Deliv Sci Technol. 2017;41:359-66.

146. Choi S, Lee H, Ghaffari R, Hyeon T, Kim DH. Recent advances in flexible and stretchable bio-electronic devices integrated with nanomaterials. Adv Mater. 2016;28:4203-18.

147. Someya T, Bao Z, Malliaras GG. The rise of plastic bioelectronics. Nature. 2016;540:379-85.

148. Kim J, Ghaffari R, Kim D-H. The quest for miniaturized soft bioelectronic devices. Nat Biomed Eng. 2017;1:00491.

149. Zhang Y, Yu J, Wang J, Hanne NJ, Cui Z, Qian C, et al. Thrombin-responsive transcutaneous patch for autoanticoagulant regulation. Adv Mater. 2017;29.

150. Yu J, Qian C, Zhang Y, Cui Z, Zhu Y, Shen Q, et al. Hypoxia and $\mathrm{H}_{2} \mathrm{O}_{2}$ dual-sensitive vesicles for enhanced glucose-responsive insulin delivery. Nano Lett. 2017;17:733-9.

Publisher's note Springer Nature remains neutral with regard to jurisdictional claims in published maps and institutional affiliations. 